Elżbieta Pokorzyńska

Katedra Informacji Naukowej i Bibliologii

Uniwersytet Kazimierza Wielkiego w Bydgoszczy, Bydgoszcz, Polska

e.pokorzynska@ukw.edu.pl

ORCID 0000-0001-7918-8226

http://doi.org/10.33077/zbkh.2018.12.pokorzynska

\title{
Źródła do badań nad historią introligatorstwa polskiego XIX-XX wieku
}

\begin{abstract}
Sources for research on the history of Polish bookbinding in the $19^{\text {th }}-20^{\text {th }}$ century

Access to these sources is hindered due to lacking bibliographies and documentary reviews. The author applies traditional typoogy of bibliological sources to present potential storage location of specific types of documents, and their potential usefulness in different types of research problems. Search methods and recommended direction of further studies are also discussed. Particular attention is paid to the possibilities offered by digitalisation of library and archival resources.
\end{abstract}

Key words: bookbinding - history of bookbinding $19^{\text {th }}-20 t^{\mathrm{h}}$ century - historical sources. Słowa kluczowe: introligatorstwo - oprawoznawstwo - historia introligatorstwa XIX-XX w. źródła historyczne.

Choć stulecia XIX i XX są epoką nieodległą, to badania nad introligatorstwem tego czasu sprawiają wiele trudności, wśród których dotarcie do źródeł jest problemem podstawowym. Na skutek dziejowych zawirowań, przemian ustrojowych i wojennych zniszczeń przerwana została ciągłość bytu większości zakładów i organizacji introligatorskich, a ich dokumenty rozproszone lub zniszczone. Postulat utworzenia przewodnika po dokumentach archiwalnych dotyczących introligatorstwa, przedstawiony przez autorkę w konkursie grantowym, nie zyskał akceptacji grantodawcy, ale pozostaje wciąż aktualny.

Niniejszy artykuł nie aspiruje do wyczerpującego przedstawienia bazy źródłowej do badań nad historią introligatorstwa polskiego XIX-XX w., celem jego jest raczej przedstawienie różnego typu źródeł oraz wskazanie sposobu ich poszukiwania. Doceniając wysoką wartość porządkującą typologii 
wypracowanej przez Jacka Puchalskiego dla źródeł do historii bibliotek ${ }^{1}$, spróbowano spożytkować tę klasyfikację na polu badań nad introligatorstwem, jednak odmienna specyfika działalności bibliotek i introligatorni, różnice w systemie podległości oraz nieporównanie mniejsza skala zachowanych źródeł kazały zarzucić ten plan. Zdecydowano się na przyjęcie tradycyjnego podziału źródeł na pisane i niepisane, tych pierwszych na archiwalne (dokumenty) i drukowane. Za źródła archiwalne uznano nie tylko te, które są przechowywane w archiwach, lecz takie, które mają charakter unikatowych dokumentów (w tym także te, które doczekały się wydań naukowych). Bywają one przechowywane $\mathrm{w}$ różnych instytucjach, a nierzadko pozostają w rękach prywatnych. W stosunku do nich zastosowano w pewnym zakresie klasyfikację Puchalskiego, wyodrębniając w źródłach tego typu materiały różnego rodzaju urzędów nadrzędnych, dokumenty samych introligatorów oraz innych instytucji współpracujących z introligatorami. Wśród źródeł drukowanych wydzielono akty normatywne, wydawnictwa informacyjne i akcydensowe oraz materiały opisowe. Na źródła niepisane składają się oprawy książkowe, warsztaty introligatorskie $\mathrm{i}$ ich wyposażenie oraz ikonografia.

\section{1. Źródła archiwalne}

\subsection{Dokumenty urzędowe}

Podczas pełnienia swych obowiązków urzędy różnego rodzaju (magistrackie, rządowe, policyjne) wytwarzały dokumenty, z których część wydawano petentom, a część pozostawała $\mathrm{w}$ aktach, $\mathrm{z}$ biegiem czasu trafiając do archiwów. Poszukiwanie dokumentów archiwalnych może przebiegać systemowo lub wyrywkowo. Przeszukiwanie systemowe możliwe jest w przypadku akt dokumentujących pewne rodzaje działalności. Potencjalnym źródłem wiedzy o introligatorach może być np. dokumentacja podatkowa, rejestracja zakładów, nadawanie uprawnień, dokumenty magistrackie dotyczące spraw ekonomicznych. Poszukiwania można prowadzić poprzez inwentarze archiwalne, na przykład odnaleziono bogate materiały dotyczące introligatorstwa w aktach miejskich Torunia, w dokumentacji dotyczącej handlu, rzemiosła i przemysłu².

Drogą do odnalezienia źródeł dotyczących introligatorstwa może być także eksploracja dokumentów izb rzemieślniczych. Te powołane na początku

J. Puchalski, Źródła do historii bibliotek w Polsce w latach 1918-1947. Studium bibliologiczne, Warszawa 2007, s. 95-96.

2 AP w Toruniu, sygn. 69/1c, sekcja 6, Rzemiosło, handel, przemysł; materiały stały się podstawą opracowania autorki: Introligatorzy toruńscy $w$ XIX i pierwszej połowie XX wieku, [w:] Dawnych ksiag niesyty. Tom studiów dedykowanych profesorowi Januszowi Tondelowi na siedemdziesięciolecie urodzin, pod red. I. Imańskiej, A. Wagnera, Toruń 2016, s. 317-339. 
$\mathrm{XX}$ w. instytucje sprawowały na różne sposoby nadzór i opiekę nad rzemiosłem. Jednym z ich zadań było przeprowadzanie egzaminów i nadawanie uprawnień zawodowych. Analiza zespołu archiwalnego Izby Rzemieślniczej w Bydgoszczy ujawniła materiały związane z komisją przeprowadzającą egzaminy dla introligatorów: metodyką jej działań, osobami, zarówno członkami komisji, egzaminowanymi uczniami jak i ich nauczycielami - mistrzami ${ }^{3}$.

Impulsem do podjęcia badań wyrywkowych bywa wskazówka znaleziona w publikacji lub bibliografii załącznikowej, wówczas bez przedzierania się przez niezliczone inwentarze można bezpośrednio trafić do interesujących materiałów. W zakresie XIX-wiecznej historii książki niezwykle cenne są prace Mariana Lecha, który w swoich publikacjach nie tylko wykorzystywał źródła archiwalne, ale również publikował je oraz wskazywał warte dalszego zbadania zespoły dokumentów ${ }^{4}$. Wartość takich wskazówek nie ogranicza się do szybkiego dotarcia do opisanych materiałów, ale też pozwala podjąć penetrację sąsiadujących zapisów w inwentarzach archiwalnych w poszukiwaniu podobnych dokumentów.

Wskazówki bibliograficzne skierowały autorkę do różnego rodzaju źródeł urzędowych. Były to np. rejestry obywateli ${ }^{5}$, rejestry przybyszów (zarówno w dokumentacji policyjnej, jak i w sprawach o nadanie obywatelstwa), bo $\mathrm{w}$ tych materiałach znajdują się adnotacje o wykonywanym zawodzie ${ }^{6}$. Idąc za wskazówkami M. Lecha odnaleziono dokumenty Starszego Inspektora Fabrycznego Guberni Warszawskiej, który dokonał kontroli w kilku warszawskich fabrykach introligatorskich ${ }^{7}$ oraz Warszawskiego Gubernialnego Urzędu do spraw Stowarzyszeń, który rejestrował wnioski o założenie organizacji drukarsko-introligatorskich ${ }^{8}$.

Spośród różnego rodzaju dokumentów archiwalnych potencjalnym źródłem do badań nad introligatorstwem mogą być akta notarialne, hipoteczne

3 AP w Bydgoszczy, sygn. 6/651/9, Ewidencja złożonych egzaminów mistrzowskich; sygn. 6/651/40, Akten betr. Abnahme von Gesellenprüfungen im Buchbinderhandwerk, sygn. 6/651/41, Akta egzaminów czeladniczych dla introligatorów; na podstawie tych źródeł powstało opracowanie autorki: Introligatorstwo w Bydgoszczy w świetle dokumentacji egzaminów zawodowych z lat 1901-1933, „Kronika Bydgoska” 2011, nr 33, s. 83-102.

4 M. Lech, Problematyka księgoznawcza w zasobach archiwaliów dziewiętnastowiecznych, „Studia o Książce” 1985, t. 15, s. 69-86; tenże, Materiaty do dziejów książki i czytelnictwa w okresie zaborów w archiwach polskich, „Rocznik Biblioteki Narodowej” 1969, t. 5, s. 23-57; tenże, Książa i czytelnictwo $w$ Warszawie 1870 r. w świetle raportu inspektorów nadzoru $w$ komitecie cenzury, „Rocznik Biblioteki Narodowej” 1971, t. 7, s. 395-421.

5 AGAD, sygn. 1/99 nr 15-17, Protokół rewizyi miasta wolnego Warszawy 1792.

6 AGAD, sygn. 1/191 nr 7827, 7833, 7839, 7841, Akta tyczące się imigracji; AP w Toruniu, sygn. 69/1c/18420, Wykaz przybyłych czeladników rzemieślniczych.

AP w Warszawie, sygn. 72/1151/929, Akta kontroli fabryki Leśniewskiego; sygn. 72/1151/977, Akta kontroli fabryki braci Charin.

8 AP w Warszawie, sygn. 72/1155/549, Akta dot. Towarzystwa Przemysłu Graficznego 
oraz sądowe. W chwili obecnej trudno wskazać jakiś sposób dotarcia do interesujących materiałów inną drogą niż konkretne wskazówki. Autorka uzyskała niegdyś szereg fiszek z zapiskami od Wandy Szaniawskiej, która w latach 50. i 60. XX w. realizowała systematyczną kwerendę akt notarialnych w Warszawie; takie badania prowadził również i wykorzystywał w swych publikacjach Jan Rogala, pracownik Archiwum Państwowego w Warszawie. Źródła notarialne bywają bezcenne, zwłaszcza gdy zawierają spisy majątku, w tym wyposażenia warsztatu introligatorskiego .

W ostatnich latach zasoby archiwalne stają się bardziej dostępne za przyczyną digitalizacji inwentarzy archiwalnych i akt oraz ich udostępniania w bazach internetowych NDAP. Szczególnie godna polecenia jest wyszukiwarka „Szukaj w archiwach”"10, która nie tylko przeszukuje zbiory rozproszone, ale także oferuje dostęp do akt zdigitalizowanych. Warto polecić powtarzanie w dłuższych odstępach czasu tych samych wyszukiwań, bowiem postępująca cyfryzacja zasobów przynosi stały przyrost rekordów w bazach, a co za tym idzie uzyskiwanie coraz większej liczby wyników. Przeszukiwanie baz archiwalnych może przynieść znaleziska w zaskakujących miejscach, takich jak np. dokumenty polityczne z czasów powstania styczniowego ${ }^{11}$. Poza bazami NDAP archiwa udostępniają inwentarze na własnych stronach internetowych, a niektóre tworzą różnorodne wewnętrzne bazy informacyjne, np. w AP w Warszawie opracowano bazę firm występujących w rejestrze handlowym, w którym znajduje się szereg zakładów introligatorskich ${ }^{12}$.

Bardzo bogatym zasobem źródeł historycznych są akta stanu cywilnego. Bywały one wykorzystywane w pracach dotyczących introligatorstwa, np. w studium na temat introligatorów leszczyńskich pióra Kamili Szymańskiej albo pracach J. Rogali ${ }^{13}$. Systematyczne ich przeszukiwanie jest niewykonalne ze względu na ich mnogość. Można co najwyżej dokonać kwerendy w konkretnej księdze (określona parafia) posiadając jakieś dane wyjściowe (np. data śmierci). W ostatnim czasie powstał mechanizm pozwalający na masowe wykorzystywanie tego rodzaju dokumentów. Polskie Towarzystwo

w Królestwie Polskim; sygn. 72/1155/454, Profesional'noje obščestwo tipografščikov', litografov', perepletčikov, i srodstviennych' im' professij Carstva Pol'skavo.

9 Np. AP w Warszawie, sygn. 72/714, vol. 15, nr aktu 1469, Spis inwentarza Józefa Pukszty. Został on opublikowany w: M. Mlekicka, J. Rogala, Księgarnia wydawnicza Józefa Pukszty w Warszawie (1815-1834), „Roczniki Biblioteczne” 1966, t. 10, z. 1-2, s. 91-140.

10 szukajwarchiwach.pl, [online] https://szukajwarchiwach.pl/ [dostęp 28.08.2018].

11 AGAD, sygn. $1 / 245 / 55$, Przedstawienie sprawy [...] introligatora Aleksandra Millera, czeladnika introligatorni Ignacego Leżyńskiego.

12 Wyszukiwarka - Księgi rejestrowe RHA - Archiwum Państwowe w Warszawie, [online] https://www.warszawa.ap.gov.pl/wyszukiwarki/rha/index.html [dostęp 28.08.2018].

13 K. Szymańska, Introligatorzy i księgarze w Lesznie w XVIII w., „Roczniki Biblioteczne” 1999, t. 43, s. 105-119; M. Mlekicka, J. Rogala, Księgarnia wydawnicza Józefa Pukszty... 
Genealogiczne tworzy mianowicie indeks do ksiąg stanu cywilnego oraz skonstruowało i udostępniło do użytku publicznego wyszukiwarkę „Geneteka”, która za pomocą hiperłączy oferuje dostęp do skanów poszukiwanych dokumentów ${ }^{14}$. Niestety, zawód nie jest filtrem wyszukiwawczym tego narzędzia, można jedynie prowadzić poszukiwania określonych postaci, posiadając ich dane osobowe (nazwisko, imię, daty życia). Ograniczeniem jest konieczność wyboru regionu, w którym zostanie przeprowadzone przeszukiwanie; trzeba też brać pod uwagę, że prace indeksacyjne i digitalizacyjne w poszczególnych regionach przebiegają $\mathrm{w}$ różnym tempie.

\subsection{Dokumenty introligatorów}

\subsubsection{Dokumenty organizacji introligatorskich}

Źródłami kardynalnymi są dokumenty z działalności cechów, tj. różnego rodzaju księgi. Cechy prowadziły księgi urzędowe obejmujące całokształt działalności lub księgi wyspecjalizowane: księgi protokołów, księgi mistrzów, czeladników i uczniów, księgi rachunkowe i księgi normatywne. Wiele dokumentów przechowywano luzem (np. przywileje, akty urodzenia, korespondencję), niektóre łączono w poszyty lub teki. W XX w. cechy prowadziły kroniki i albumy z fotografiami, zachowywały urzędowe pisma i wersje robocze lub kopie własnych pism, sprawozdań itp.

Zespoły archiwalne cechów introligatorskich są niekompletne, gdyż ich dokumentacja nie była archiwizowana systematycznie i według określonych zasad. Organizacje zawodowe nie podlegały organom ani instytucjom państwowym, więc ich dokumenty nie były archiwizowane z urzędu. Do archiwów trafiały niektóre z nich, ale mogły też ulegać zniszczeniu, rozproszeniu lub pozostawać w rękach prywatnych. Bywały też przekazywane całymi zespołami do archiwów w momentach zwrotnych (np. przemian prawnych), wówczas jednak nie obejmują całego okresu istnienia organizacji. Czasem zaś niektóre (najstarsze) archiwizowano jako materiały historyczne, albo też w niejasnych okolicznościach do archiwów trafiły szczątki cechowej dokumentacji ${ }^{15}$. W związku z tym stan zachowania i status akt cechów introligatorskich jest niejednolity. W Krakowie, Poznaniu i Wilnie przechowywane są w archiwach państwowych, stanowiąc wydzielony zespół archiwalny ${ }^{16}$, w Gdańsku dokumentacja introligatorów znajduje się $\mathrm{w}$ zespole akt miejskich, przemieszana $\mathrm{z}$ dokumentami

14 geneteka.genealodzy.pl, [online] http://geneteka.genealodzy.pl/ [dostęp 28.08.2018].

$15 \mathrm{Z}$ dokumentów toruńskiego cechu introligatorskiego zachował się jedynie przywilej: AP w Toruniu, sygn. 69/IV/V/1; z dokumentów cechu warszawskiego tylko Księga rachunkowa $\mathrm{z}$ lat 1811-1830: AP w Warszawie, sygn. 72/1049/13.

16 Archiwum Narodowe w Krakowie, sygn. 29/141, Cech introligatorów w Krakowie; 
wszystkich cechów ${ }^{17}$, akta lwowskie znajdują się w Muzeum Śląskim w Katowicach $^{18}$. Dokumentacja cechów w innych miastach albo nie zachowała się, albo ich miejsce przechowywania nie jest ustalone (np. w Warszawie, Toruniu, Bydgoszczy). W niektórych miastach introligatorzy nie stanowili samodzielnych zrzeszeń, lecz wchodzili w skład cechów mieszanych (np. w Radomiu) ${ }^{19}$. W naszym narodowym zasobie znalazły się dokumenty cechów z tych miast, które znalazły się w granicach państwa polskiego dopiero po II wojnie światowej (np. Szczecin, Nysa, Zielona Góra ${ }^{20}$ ). Niektóre materiały historyczne, głównie przywileje, doczekały się naukowej edycji lub reprodukcji ${ }^{21}$. Dokumenty nowsze, XX-wieczne, mogą znajdować się w biurach lub archiwach własnych cechów istniejących do dnia dzisiejszego.

Obok organizacji cechowych w omawianym okresie powstawały i funkcjonowały inne rodzaje stowarzyszeń: organizacje czeladników, związki zawodowe, organizacje przemysłowców. Wiedza o ich działaniach jest niezbędna dla pełnego obrazu środowiska zawodowego, ale stan zachowania dokumentów źródłowych z ich działalności i wiedza o nich jest niewielka. Dokumenty organizacji czeladniczych mogły zostać włączone do akt cechu, ale niekiedy pozostawały w rękach prywatnych ${ }^{22}$. Dokumenty związków zawodowych mogą znajdować się w zespołach archiwalnych tychże organizacji albo pozostawać w archiwach zakładowych związków nadal działających.

AP w Poznaniu, sygn. 53/636/14, Cech introligatorów i konwisarzy w Poznaniu; Litewskie Państwowe Archiwum Historyczne, sygn. F 975, Wileński cech introligatorów. Akta wileńskie zostały opracowane w: J. Rodkiewiczówna, Cech introligatorski w Wilnie. Zarys historyczny, Wilno 1929.

17 AP w Gdańsku, sygn. 10/300C, Cechy gdańskie. Inwentarz zespołu grupuje dokumenty poszczególnych cechów, niezależnie od ich archiwalnej sygnatury.

18 Muzeum Śląskie w Katowicach, sygn. T/46, Cech introligatorów lwowskich.

19 AP w Radomiu, sygn. 58/1335 nr 17, Książka profesji introligatorskiej w Radomiu.

20 AP w Szczecinie, sygn. 65/277, Cech introligatorów w Szczecinie; AP w Opolu, sygn. 45/121, Cech introligatorów w Nysie; AP w Zielonej Górze, sygn. 89/946, Akta cechu introligatorów i kuśnierzy w Zielonej Górze, zob. też: P. Liefhebber, Dokumenty przyjęć uczniów do cechu introligatorów i kuśnierzy w Zielonej Górze z poczatku XIX wieku, [w:] Kultura i spoleczeństwo na Środkowym Nadodrzu w XIX i XX w., pod red. P. Bartkowiaka, D. Kotlarka, Zielona Góra 2008, s. 166-173.

${ }^{21} \quad$ Prawa, przywileje i statuta miasta Krakowa (1507-1795). T. 2: (1587-1696), z. 3, zebrał i wyd. F. Piekosiński, S. Krzyżanowski, Kraków 1909, s. 1298-1324, 1331-1332; M. Żynda, Introligatorstwo poznańskie 1574-1975, Poznań 1975, wyklejka; L. Rosadziński, Ginace rzemiosło. Śladami poznańskich introligatorów, Poznań 2011, s. 22; edycja niedokończona: Statut cechu introligatorów poznańskich z roku 1574, „Polska Gazeta Introligatorska” 1929, nr 1, s. 2-3; Najstarszy dokument introligatorczyków poznańskich, tamże 1928, nr 6, s. 86-88; W. Tyszkowski, Statut Konfraternii Kunsztu Introligatorskiego we Lwowie z 1740 r., „Ze Skarbca Kultury” 1978, t. 24, nr 30, s. 37-51; Statut cechu introligatorów i szkatułkarzy z 1608 r. w: Statuty toruńskiego rzemiosła artystycznego i budowlanego z XVI-XVIII w., wyd. B. Dybaś, J. Tandecki przy współpr. M. Farbiszewskiego, Warszawa-Toruń 1990, s. 63-74, toż w polskim przekładzie dokonanym przez Witolda Szczuczko w: J. Zamrzycka, Introligatorzy toruńscy od XV do XVI/XVII wieku. Typologia cech warsztatowych, Torun 2015, s. 58-70.

22 Księga czeladnicza cechu gdańskiego znajduje się w zespole akt cechu w AP w Gdańsku 


\subsubsection{Dokumenty zakładów introligatorskich i poszczególnych introligatorów}

Zakłady introligatorskie posiadały oraz wytwarzały różnego rodzaju dokumenty. Do grupy dokumentów uzyskiwanych należą dyplomy, listy wyuczenia, książeczki czeladnicze, konsensy i patenty, będące poświadczeniem uprawnień i płaconych obciążeń finansowych oraz różnego rodzaju pisma urzędowe. Do grupy źródeł wytwarzanych przez zakłady należą dokumenty dotyczące zatrudnionej kadry, spisy, umowy i poświadczenia zatrudnienia bądź nauki, wykazy płac. W kontakcie z klientami powstawały reklamy, oferty, rachunki i kopiariusze rachunków, lecz materiały tego typu łatwiej znaleźć w archiwach klientów niż w archiwach własnych tychże zakładów.

$\mathrm{W}$ archiwach zakładów znajdują się przemieszane dokumenty, materiały drukowane i ikonograficzne: obok ksiąg pamiątkowych, dyplomów i odznaczeń znajdują się fotografie, katalogi i rachunki za zakupione maszyny, narzędzia i materiały, projekty i zdjęcia własnych prac, rękopiśmienne i drukowane materiały o charakterze podręcznikowo-technologicznym, wspomnienia i korespondencja, dokumenty osobiste, zaproszenia i karty uczestnictwa w różnych uroczystościach. Przykładem zachowanego archiwum zakładowego jest dokumentacja zakładu introligatorskiego Roberta Jahody w Krakowie, który przekształcono w placówkę muzealną ${ }^{23}$. Do dokumentacji innych zakładów bardzo trudno dotrzeć; niekiedy dokumenty znajdują się w archiwach zakładowych firm, które jeszcze istnieją lub są przechowywane w archiwach rodzinnych spadkobierców ${ }^{24}$, przeważnie jednak uległy rozproszeniu lub zniszczeniu. Szereg dokumentów, w szczególności rachunków za wykonane prace introligatorskie, wystawianych różnym klientom indywidualnym czy instytucjonalnym, znajduje się w rękach prywatnych - często trafiają one na rynek antykwaryczny, bywają oferowane na platformie Allegro i chętnie są gromadzone przez bibliofilów; spore ich zbiory posiadają kolekcjonerzy introligatorskich pamiątek ${ }^{25}$.

(sygn. 300C/1143a), podobnie jak księgi czeladnicze w AP w Krakowie (sygn. 29/141/23-29), natomiast poznańska książka czeladników introligatorskich znajduje się z rękach Leonarda Rosadzińskiego, który stworzył wystawę introligatorską, zob. A. Nowakowski, L. Rosadziński, «Witajcie koledzy» - poznańska «Książka wpisów wędrujących czeladników introligatorskich», „Biblioteka” 2010, nr 14, s. 21-31; L. Rosadziński, Ginace rzemiosło..., s. 43-47.

23 Drukarstwo $i$ introligatorstwo, Muzeum Historyczne Miasta Krakowa, [online] http://www.mhk.pl/zbiory/drukarstwo-i-introligatorstwo [dostęp 08.08.2018]. Część dokumentacji tego zakładu znalazła się w Archiwum Narodowym w Krakowie, sygn. 29/648.

24 Autorka dotarła do spadkobierców wielu introligatorów (np. Jana Recmanika, Zygmunta Zjawińskiego, Zdzisława Szafranka, Zofii Dębickiej, Aleksandra Semkowicza, Stanisława Chyły); w rodzinnych archiwach przechowywano materiały, które chętnie udostępniano.

25 Pamiątki introligatorskie kolekcjonuje L. Rosadziński z Poznania (zob. przypis 22) oraz Leszek Knyrek z Bydgoszczy (zob. przypis 84). 
Lepiej zachowane są archiwalia zakładów introligatorskich niesamodzielnych, będących działami instytucji, w szczególności państwowych (bibliotek, więzień). W takim przypadku materiały dotyczące warsztatów introligatorskich znajdują się w zespołach archiwalnych tych instytucji, po części w wydzielonych teczkach, a po części zmieszane z dokumentami ogólnymi ${ }^{26}$. Dokumentacja zakładów uspołecznionych z okresu PRL-u była zachowywana i znajduje się w archiwach państwowych.

\subsection{Akta instytucji i osób współpracujących}

Myśląc o instytucjach bądź osobach współpracujących trzeba mieć na uwadze producentów i dostawców materiałów, maszyn i narzędzi, a także klientów zakładów introligatorskich. Niestety, autorce nie jest znany żaden zespół archiwalny producenta ani sprzedawcy ${ }^{27}$, natomiast wśród klientów w pierwszym rzędzie warto zwrócić uwagę na biblioteki, które zamawiały oprawy książek i innych zbiorów. Dokumenty dotyczące spraw introligatorskich zostały ujawnione w archiwach wielu bibliotek, w wielu innych czekają na odnalezienie; jest to potencjalnie najbogatszy rodzaj źródeł do przebadania i wykorzystania.

Usługi introligatorskie były opłacane $\mathrm{z}$ funduszy bibliotek, stąd $\mathrm{w}$ ich aktach znajdują się przede wszystkim dokumenty o charakterze finansowym. Główny rodzaj stanowią listy książek przekazywanych zakładowi introligatorskiemu do oprawy wraz z rozliczeniami za wykonanie zlecenia. Biblioteki posiadające duże zbiory zakładały specjalne książki, w których wpisywano dane woluminów oddawanych do oprawy. Widnieją tam daty oraz nazwiska

26 Przykładowo: akta introligatorni Biblioteki Miejskiej (WiMBP) w Bydgoszczy są przechowywane w Dziale Zbiorów Specjalnych oraz w dokumentacji Sekcji Kadr, a także w AP w Bydgoszczy, w zespole Zarządu Miejskiego (sygn. 6/899), któremu podlegała Biblioteka. Akta zostały wykorzystane w opracowaniu autorki Z dziejów introligatorni Wojewódzkiej i Miejskiej Biblioteki Publicznej im. dr. Witolda Betzy w Bydgoszczy, Bydgoszcz 2013. Akta introligatorni Z. Szafranka działającej w BP w Warszawie na ul. Koszykowej znajdują się w Archiwum Biblioteki; ich wyszukiwanie umożliwia Katalog rękopisów Biblioteki Publicznej m. st. Warszawy. T. 1: Sygnatury 1-200, oprac. J. Rudnicka, J. Górka, Warszawa 1974. Akta introligatorni i pracowni konserwacji BN w Warszawie przechowywane są w archiwum zakładowym BN, sygn. 1.552, 2.107. Akta introligatorni Ossolineum znajdują się w Archiwum Zakładu Narodowego im. Ossolińskich, przechowywanym w Oddziale Rękopisów Lwowskiej Narodowej Naukowej Biblioteki Ukrainy im. W. Stefanyka (Львівська національна наукова бібліотека України імені В. Стефаника). Dokumenty te zostały zeskanowane i są udostępniane w bazie internetowej zasobów cyfrowych Zakładu Narodowego im. Ossolińskich we Wrocławiu, [online] http://bazy.oss.wroc.pl/kzc/ [dostęp 08.08.2018]. Wykorzystała je Ewa Goumissi w opracowaniu Ochrona książek i rękopisów w Zakładzie Narodowym im. Ossolińskich we Lwowie w latach 1900-1939, [w:] Ochrona zbiorów bibliotecznych. Praca zbiorowa, pod red. R. Nowickiego, J. Gomoliszek, K. Wodniak, Bydgoszcz 2016, s. 35-54.

27 Zob. przypis 50. 
introligatorów, płacone kwoty, sporadycznie pojawiają się zalecenia co do sposobu oprawy. Niektóre książki mają charakter indywidualny - wykazy woluminów kierowane do jednego introligatora, inne są zbiorcze i pokazują, że biblioteki zmieniały usługodawców lub współpracowały z kilkoma warsztatami jednocześnie ${ }^{28}$. W poszytach, obok dokumentów finansowych, znajdują się oferty zakładów introligatorskich, reklamy, czasami dokumenty potwierdzające ich status prawno-podatkowy ${ }^{29}$ oraz instrukcje dotyczące sposobu, w jaki winne być oprawiane książki ${ }^{30}$.

Innymi instytucjami, korzystającymi z usług introligatorów były różnego rodzaju urzędy i biura; $w$ ich zespołach archiwalnych mogły pozostać dokumenty z tej współpracy. Bogata dokumentacja, która zachowała się w aktach Komisji Rządowej Przychodów i Skarbu Królestwa Polskiego (1821-1869), pozwoliła na analizę rodzaju robót realizowanych przez introligatorów, mechanizmów pozyskiwania klientów/kontrahentów, stanowiła też bogate źródło informacji o poszczególnych introligatorach. W związku z tym, że urząd ten stosował dość popularną w XIX w. metodę pozyskiwania usługodawcy w drodze przetargu i zawierania z nim czasowego kontraktu, większość

28 Np. w Dziale Rękopisów BUW zachowały się książki z połowy XIX w., dokumentujące współpracę z introligatorami Karolem Bagińskim, Franciszkiem Estreicherem, Janem Piotrowskim, Motelem Wildemanem, sygn. 114-117/I. W późniejszym czasie prowadzono książki zbiorcze, zob. BUW, sygn. 167/IV, 309/IV, 15-16/V. Dokumenty usług introligatorskich świadczonych Czytelniom Bezpłatnym Warszawskiego Towarzystwa Dobroczynności są rozproszone w aktach WTD przechowywanych w Archiwum BP m.st. Warszawy, sygn. A1, A8-11, A74-79, A91. Dokumentacja zleceń introligatorskich dla Biblioteki Kórnickiej zachowała się w Dziale Rękopisów tejże książnicy, także jako całościowe księgi, np. „Rachunki introligatorskie” lub „Oprawa książek”, zob. sygn. AB215-AB219. Materiały te zostały wykorzystane przez Elżbietę Jabłońską w pracy Biblioteka Kórnicka skarbnica zbiorów Dziatyńskich i Zamoyskich, Torun 2005. Archiwalia Biblioteki Wilanowskiej były pożytkowane przez Jadwigę Rudnicką (Biblioteka Wilanowska, Warszawa 1966) oraz Katarzynę Garczewską-Semkę (Ozdobne montaże rysunków z kolekcji wilanowskiej: historia i materialy w świetle źródet archiwalnych i konserwacja rysunku Norblina «Zaprzysiężenie Konstytucji 3 Maja 1791», „Notes Konserwatorski” 2015, nr 17, s. 209-227). Archiwalia Kapituły Włocławskiej kryją dokumenty związane z biblioteką, w tym z oprawą ksiąg; wykorzystała je Bernardeta Iwańska-Cieślik w dwóch pracach: Biblioteka kapituły katedralnej we Włocławku, Bydgoszcz 2013 oraz Kapituła zleca oprawę ksiag - analiza rachunków i innych dokumentów kapituły katedralnej we Włocławku w poszukiwaniu opłat za uslugi introligatorskie w latach 1492-1863, [w:] Introligatorzy $i$ ich klienci $=$ Bookbinders and their customers, pod red. A. Wagnera, Toruń 2017, s. 213-228. O analogicznych materiałach w bibliotece Baworowskich informowali Agnieszka Biały i Karol Makles w referacie Źródła do badań biblioteki hr. W. Baworowskiego w zbiorach Lwowskiej Narodowej Naukowej Biblioteki Ukrainy im. W. Stefanyka wygłoszonym podczas III Ogólnopolskiej Konferencji Naukowej „Z dziejów książki i prasy”, Bydgoszcz 2015.

29 Np. w Archiwum BP m.st. Warszawy, sygn. 341/3 k. 84, znajduje się odpis Świadectwa Przemysłowego Introligatorni Artystycznej W. Michalskiej.

30 Archiwum BP m.st. Warszawy, sygn. A91, Oprawa i konserwacja książek w czytelniach bezpłatnych, 1895, k. 92-93; Archiwum Zakładowe BN, sygn. 107, Przepis na oprawę zwyczajną, k. 21-22. 
dokumentów stanowią liczne wersje i brudnopisy kontraktów, cenników, protokołów i pism przewodnich ${ }^{31}$.

Do klientów introligatorni należeli wydawcy, drukarze i księgarze, zlecający oprawę nakładów wychodzących z drukarni. W materiałach archiwalnych można znaleźć dokumenty tej działalności, choć zachowane archiwa firm wydawniczo-księgarskich należą do rzadkości. Informacje o zleceniach introligatorskich znaleziono np. w księdze rachunków drukarni w Toruniu z końca XVIII w. czy w wydanych aktach władz powstania kościuszkowskiego związanych z działalnością wydawniczą ${ }^{32}$.

\section{2. Źródła drukowane}

Cechą odróżniającą te materiały źródłowe od ujętych w pierwszej grupie źródeł dokumentalnych jest ich powtarzalność. Były drukowane w wieloegzemplarzowych nakładach, co zwiększa szansę, że zachowały się w większej liczbie egzemplarzy i mogą być przechowywane (a zatem dostępne) w wielu zbiorach. Bardziej prawdopodobne i łatwiejsze jest odnalezienie ich w systemie informacji bibliograficzno-katalogowej.

\subsection{Akty normatywne}

W okresie staropolskim rzemiosło kierowało się przede wszystkim przywilejami nadawanymi poszczególnym organizacjom cechowym. Przymus cechowy utrzymał się jeszcze przez połowę XIX stulecia w zaborze austriackim, w innych zaborach odejście od ustroju cechowego nastąpiło wkrótce po rozbiorach. Akty normatywne regulowały zasady prawne dla prowadzenia działalności gospodarczej i funkcjonowania grupy społecznej: albo członków określonego cechu, bądź rzemieślników w ogólności, albo wręcz osób uczestniczących w wytwórczości (tu: introligatorskiej). W ostatnim przypadku mogli to być nie tylko majstrowie, czeladnicy i uczniowie, ale też członkowie rodzin mistrzów cechowych, właściciele fabryk, kierownicy zakładów, wykwalifikowani i niewykwalifikowani robotnicy i robotnice a nawet nieletni zatrudniani w fabrykach.

W zaborze rosyjskim podstawowym aktem prawnym regulującym funkcjonowanie rzemiosł wszystkich profesji było Postanowienie Xięcia Namiestnika

31 AGAD, sygn. 1/194/1420-1422, Roboty introligatorskie. Materiały zostały wykorzystane przez autorkę w artykule Introligatorzy warszawscy w świetle akt Komisji Rządowej Przychodów i Skarbu z lat 1822-1869, „Rocznik Warszawski” 2007, nr 35, s. 285-309.

32 AP w Toruniu, sygn. XVI/122, Rechnungen von der Raths-Buchdruckerei aus der Jahren 1782-1792; H. Oprawko, J. Szczepaniec, Materiaty do działalności wydawniczej naczelnych władz powstańczych 1794 roku w Warszawie, ,Ze Skarbca Kultury” 1964, t. 12, z. 16, s. 214-295. 
Królewskiego [Józefa Zajączka] względem urządzenia zgromadzeń rzemieślniczych ... wydane w 1816 r., zwane ,ustawą o zgromadzeniach” lub ,ustawą zgromadzeń rzemieślniczych"33. Dokument ten był wielokrotnie publikowany, nie tylko w postaci samoistnej, ale też jako ogłoszenie w „Dzienniku Praw”, oraz w zbiorczym wydaniu przepisów prawnych. Najwcześniej, tuż po ogłoszeniu, został zamieszczony w „Gazecie Warszawskiej”, zaś najwartościowszą jego edycją jest wydanie nieurzędowe w „Gazecie Przemysłowo-Rzemieślniczej” w 1905 r., wzbogacone o późniejsze uzupełnienia. Tekst ustawy dostępny jest także w formie wtórnej, czy to w zdigitalizowanej „Gazecie Warszawskiej”, czy w edycji źródłowej dołączonej do tomu studiów $Z$ dziejów rzemiosła warszawskiego ${ }^{34}$.

Prawodawstwo zaboru pruskiego otwiera Ordynacja rzemieślnicza z 1774 r. Jej oryginał znajduje się m.in. w Muzeum Okręgowym w Bydgoszczy, a wersję zdigitalizowaną udostępnia Elbląska Biblioteka Cyfrowa ${ }^{35}$. W roku 1845 został wydany Allgemeine Gewerbe-Ordnung ${ }^{36}$, zwany po polsku regulaminem procederowym. Był także wydany w języku polskim, co odnotowuje Bibliografia polska Karola Estreichera ${ }^{37}$, jednak nie udało się dotychczas zlokalizować żadnego egzemplarza tej edycji. Kolejnym aktem prawnym była ustawa przemysłowa (Gewerbeordnung, 1869) pierwotnie

33 Postanowienie Xięcia Namiestnika Królewskiego de dato 31. Grudnia 1816 Roku względem urządzenia zgromadzeń rzemieślniczych, [b.m.], 1816. Wg katalogu NUKAT oryginały znajdują się w BUW oraz w Bibliotece UMK w Toruniu.

34 „Dziennik Praw” 1818, t. 4, s. 111-151; Zbiór przepisów administracyjnych Królestwa Polskiego, Warszawa 1866, t. 1, cz. 2, tytuł 2, s. 3-11; „Gazeta Przemysłowo-Rzemieślnicza” 1905, nr 9, s. 69-70, nr 10, s. 78-79, nr 11, s. 85-86, nr 12, s. 94, nr 13, s. 103, nr 14, s. 107, nr 15, s. 118, nr 16, s. 126; ,Gazeta Warszawska” 1817, nr 3, dod. s. 51-52, nr 4, s. 67-76, nr 5, s. 91-93 (dostępna w bibliotece cyfrowej Polona); Z dziejów rzemiosła warszawskiego, pod red. B. Grochulskiej, W. Prussa, Warszawa 1983, s. 318-323.

35 Handwerks-Ordnung für West-Preußen = Ordynacya Rzemieślnicza lub Utożenie porządkow rzemieślniczych dla Pruss Zachodnich. De Dato Berlin den 24. Januar 1774, Marienwerder 1774; wersja cyfrowa, zob. [online] http://dlibra.bibliotekaelblaska.pl/dlibra/doccontent?id=6072 [dostęp 28.08.2018].

36 Die allgemeine Gewerbe-Ordnung, „Allgemeine Gesetzsammlung” 1845, t. 5, nr 2541; wydanie samoistne: Allgemeine Gewerbe-Ordnung für die Preußischen Staaten, nebst dem dazu gehörigen Entschädigungs-Gesetz: erlassen zu Berlin am 17. Januar 1845, Aachen 1845 (egzemplarze w zbiorach BUW i Biblioteki UMK).

37 Powszechny regulamin procederowy z dnia 17 Stycznia 1845. Ustawa tyczaca się zaprowadzenia rad procederowych i różnych odmian powszechnego regulaminu procederowego, tudzież zaprowadzenia sadów procederowych z dnia 9. lutego 1849. Instrukcya dla ustanowionych podtug § 37. 38. urządzenia $z$ dnia 9. Lutego 1849, examinacyjnych komisyjów, Brodnica 1853. Obok Bibliografii polskiej K. Estreichera (t. 4, s. 34) publikację odnotowuje także Alfons Mańkowski w artykule Dzieje drukarstwa i piśmiennictwa polskiego w Prusiech Zachodnich wraz ze szczegółowa bibliografią druków polskich zachodniopruskich, „Roczniki Towarzystwa Naukowego w Toruniu” 1906, R. 13, s. 287, odbitka - Toruń 1906. Żadnego egzemplarza nie rejestruje ani NUKAT ani BN. 
obejmująca Związek Północnoniemiecki, od 1883 r. całą Rzeszę ${ }^{38}$. W roku 1896 wprowadzono poważne zmiany w tym akcie - w polskich bibliotekach znajdują się różne wydania Gewerbeordnung po tej zmianie. Teksty wszystkich omawianych aktów prawnych są dostępne w Wikisource ${ }^{39}$.

W Wolnym Mieście Krakowie senat miasta w 1820 r. wprowadził Prawo o urządzeniu kunsztów, rzemiost i professyi ${ }^{40}$, które skonkretyzowano w roku 1843 przepisami rozporządzenia Urządzenia Cechowe ${ }^{41}$. Wcześniej, bo w 1833 r. wprowadzono prawo tworzenia żydowskich cechów filialnych $^{42}$.

W zaborze austriackim bardzo długo obowiązywały dawne monopole cechowe, dopiero w 1859 r. wprowadzono liberalny kodeks przemysłowy - Gewerbeordnung. Jego tekst wraz z późniejszymi zmianami jest dostępny online ${ }^{43}$. Prawo to obowiązywało w Galicji oraz we włączonym do niej w 1846 r. Krakowie.

Przez pierwsze lata niepodległej Polski obowiązywały przepisy z okresu zaborów, zróżnicowane w każdej części kraju. Status rzemiosła został określony nowym prawem przemysłowym wydanym w $1927 \mathrm{r}$. Zdigitalizowane rozporządzenie Prezydenta RP w tej sprawie znajduje się w bazie Internetowy System Aktów Prawnych ${ }^{44}$.

38 Gewerbeordnung für den Norddeutschen Bund, „Bundesgesetzblatt des Norddeutschen Bundes” 1869, nr 26, s. 245-282; Gewerbeordnung für das Deutsche Reich, „Deutsches Reichsgesetzblatt" 1883, nr 15, s. 177-240.

39 Gewerbeordnung für den Norddeutschen Bund, [online] https://de.wikisource.org/wiki/ Gewerbeordnung_f\%C3\%BCr_den_Norddeutschen_Bund [dostęp 30.08.2018]; Bekanntmachung, betreffend die Redaktion der Gewerbeordnung für das Deutsche Reich, [online] https://de.wikisource.org/wiki/Bekanntmachung, betreffend_die_Redaktion_der_Gewerbeordnung_f $\% \mathrm{C} 3 \% \mathrm{~B}$ Cr_das_Deutsche_Reich [dostęp 30.08.2018].

40 Prawo o urządzeniu kunsztów, rzemiost i professyi. Ustawa z 30 grudnia 1820, „Dziennik Rozporządzeń Rządowych Wolnego, Niepodległego i Ściśle Neutralnego Miasta Krakowa i jego Okręgu" 1821, nr 78, [online] https://jbc.bj.uj.edu.pl/dlibra/publication/173381/edition/164992/ [dostęp 30.08.2018].

41 Urzadzenia cechowe. Rozporzadzenie Senatu Rządzacego z 26 maja 1843, „Dziennik Praw Wolnego Miasta Krakowa" 1843, nr 2650, [online] https://jbc.bj.uj.edu.pl/dlibra/publication/133073/edition/125261/ [dostęp 30.08.2018].

42 Prawo urządzenia cechu żydowskiego z 16 września 1833, „Dziennik Praw Wolnego Miasta Krakowa" 1833, nr 6341, [online] https://jbc.bj.uj.edu.pl/dlibra/publication/444973/ edition/420107/ [dostęp 30.08.2018].

43 Kaiserliches Patent vom 20. December 1859, womit eine Gewerbe-Ordnung für den ganzen Umfang des Reiches, mit Ausnahme des venetianischen Verwaltungsgebietes und der Militärgränze, erlassen, und vom 1. Mai 1860 angefangen in Wirksamkeit gesetzt wird, ,Reichs Gesetz-Blatt für das Kaisertum Oesterreich" 1859, nr 227, s. 619-644; F. Seltsam, E. Posselt, Die österreichische Gewerbe-Ordnung, wyd. 2, Wien 1885, http://dlib-pr.mpier.mpg.de/m/kleioc/0010/exec/books/\%22202568\%22.

44 Rozporządzenie Prezydenta Rzeczypospolitej z dnia 7 czerwca 1927 r. o prawie przemysłowym, ,Dziennik Ustaw” 1927, nr 53, s. 697-720, [online] http://prawo.sejm.gov.pl/isap.nsf/download.xsp/WDU19270530468/O/D19270468.pdf [dostęp 29.08.2018]. 
Znacznie słabiej upowszechniane były inne akty prawne, np. tylko w formie wtórnej znane jest autorce rozporządzenie wydane w Warszawie dotyczące egzaminów rzemieślniczych, będące uzupełnieniem ustawy sejmu Królestwa Polskiego o zgromadzeniach z $1816 \mathrm{r}^{45}$ Wielu innych zarządzeń (przepisów dotyczących patentów, konsensów, podatków) nie udało się autorce zidentyfikować i odnaleźć pełnych tekstów, natomiast w prasie z epoki oraz $\mathrm{w}$ różnych opracowaniach spotyka się informacyjne wzmianki oraz interpretacje, które można uznać za źródła pochodne.

\subsection{Wydawnictwa informacyjne i akcydensowe}

Podstawowym typem wydawnictw informacyjnych są księgi adresowe. Publikowane od drugiej połowy XIX w. w wielu miastach, obok części urzędowej zawierały adresografię firm handlowych, rzemieślniczych, fabrycznych, niekiedy wykazy wszystkich mieszkańców miasta oraz spis posesji (taryfę), wreszcie dział reklamowy. W wieku następnym, wraz z rozwojem telefonii i bankowości pojawiają się książki telefoniczne oraz spisy kont bankowych, a wraz z rozwojem przemysłu - księgi gospodarcze, przedstawiające profil, wyposażenie oraz kapitałową skalę działalności przedsiębiorstw ${ }^{46}$. Wykazy firm choć dalece niekompletne, selektywne, były zamieszczane także w przewodnikach po miastach oraz w kalendarzach. W tych ostatnich można znaleźć reklamy, dane o stawkach podatkowych oraz fragmenty regulacji prawnych. Wszystkie te wydawnictwa służą badaniom historycznym i dlatego są w pierwszym rzędzie digitalizowane i umieszczane w kolekcjach regionaliów w poszczególnych bibliotekach cyfrowych.

Kolejny typ źródeł informacyjnych to publikacje wydawane przy okazji wystaw. Różnego rodzaju wystawy przemysłowe - krajowe i zagraniczne, organizowane od początku XIX w. miały za zadanie promowanie i wspieranie wytwórczości i przemysłu. Towarzyszyły im publikowane listy wystawców, z ich adresografią i wykazem prezentowanych wytworów. Czasem katalogi uzupełniano listą przyznanych nagród ${ }^{47}$. Szczególne miejsce wśród nich zajmują katalogi wystaw introligatorskich. Pierwsza z nich odbyła się

45 Przepisy $w$ przedmiocie zadawania sztuk czeladniczych i mistrzowskich wydane $w$ Warszawie dnia 21 kwietnia 1819 r. przez Radce Stanu Prezydenta Municypalności i Policyi Miasta Stołecznego Warszawy. Edycja tego źródła w: Z dziejów rzemiosła..., s. 316-318; przepisy zostały omówione i częściowo zacytowane w artykule L. Hohensee, Sztuki egzaminacyjne naszych pradziadów, „Rzemiosło” 1948, nr 11, s. 15-18.

46 „Przemysł Fabryczny w Królestwie Polskiem” R. 4: 1908, R. 5: 1909, R. 6: 1910; „Przemysł i Handel Królestwa Polskiego” 1913, R. 9; „Księga Adresowa Przemysłu, Handlu i Finansów" 1922 i 1926.

47 A.M. Drexlerowa, Wystawy wytwórczości Królestwa Polskiego, Warszawa 1999; taż, A.K. Olszewski, Polska i Polacy na powszechnych wystawach światowych 1851-2000, Warszawa 2005 . 
w Warszawie w roku 1897, druga w Krakowie w $1909^{48}$. Od początku wieku XX organizowano wystawy opraw historycznych i artystycznych; wiele z nich miało swoje katalogi, które są nie tylko pamiątką, ale i cennym źró$\mathrm{dłem}^{49}$.

Przydatnym źródłem informacyjnym są katalogi maszyn, narzędzi i utensyliów oraz materiałów introligatorskich. Pomagały w zaopatrzeniu warsztatów, a dziś są skarbnicą wiedzy o tym, jakie technologie znano i używano w XIX i XX w. Na ostateczny stan oprawy składało się wiele czynników, nie tylko umiejętności samych introligatorów, ale też specjalne materiały, np. fakturowe papiery, płótna i skóry, wzorzyste papiery czy tłoki, zarówno pojedyncze, jak i przystosowane do zestawiania kompletów. Ostateczna postać oprawy jest zatem także zasługą wytwórców półfabrykatów i narzędzi. Niektóre katalogi są trudno osiągalne, ale np. katalogi maszyn lipskiej firmy Karla Krausego są dostępne w internecie ${ }^{50}$.

Mniejsze znaczenie w badaniach nad introligatorstwem niż nad innymi segmentami rynku wydawniczego mają katalogi i inseraty wydawnicze i księgarskie. Niekiedy zawierają informacje o oprawach, ich rodzajach i cenach, mogą więc stanowić źródło do badań nad oprawą wydawniczą ${ }^{51}$. Za to cennym źródłem są współczesne katalogi antykwarskie i aukcyjne. W dawniejszych katalogach rzadko zwracano uwagę na oprawę, jednak od kilkunastu lat antykwariusze dostrzegli potencjał tkwiący w starannym opisie i dokumentacji fotograficznej opraw. Katalogi aukcyjne zawierają ikonografię, informacje o introligatorach sygnujących oprawy, pozwalają na kompletowanie ich dossier oraz na rejestrowanie opraw powtarzających się (wydawniczych).

Wśród druków okazjonalnych warto wyróżnić sprawozdania - dla badań nad historią introligatorstwa polskiego XIX-XX w. najwartościowsze są

48 Katalog Wystawy Introligatorskiej, Warszawa 1897; Wystawa introligatorska w Miejskim Muzeum Przemysłowym w Krakowie, Kraków 1910; rec. wystawy: J. Warchałowski, Książka, Kraków 1909.

49 Np. Pamiatki starej Warszawy zebrane na wystawie urzadzonej staraniem T.O.N.Z.P. w maju i czerwcu 1911 roku, Warszawa 1911; Pięć wieków drukarstwa warszawskiego, opr. M. Rulikowski, Warszawa 1922; Wystawa oprawy ksiązki urzadzona staraniem Towarzystwa Mitośników Ksiażki w Krakowie w sali Racławickiej Muzeum Narodowego czerwiec-lipiec MCMXXV, [tekst M. Jarosławiecka, S. Komornicki], Kraków 1925; Katalog wystawy pięknej książki polskiej, Warszawa 1936; Katalog wystawy ksiązki lwowskiej od XVI do XIX wieku, Lwów 1928; Oprawy polskie, pod red. A. Żółtowskiego, Warszawa 1987.

50 K. Krause, Gesammt-Catalog von Maschinen für die gesammte Papierindustrie, Leipzig 1899, [online] https://bildsuche.digitale-sammlungen.de/index.html?c=viewer\&bandnummer=bsb00076753\&pimage $=3 \& \mathrm{v}=100 \&$ nav $=\& \mathrm{l}=$ de [dostęp 29.08.2018]. W katalogu tym zamieszczano informacje, do jakich zakładów sprzedano dotychczas poszczególne maszyny. Znajdują się w nim między nimi firmy polskie.

51 Wyróżniają się dwa katalogi Księgarni Świętego Wojciecha wydane w Poznaniu ok. 1934 r.: Mszaly rzymskie w krajowych oprawach (wileńskich) oraz Mszaty rzymskie w polskiej szacie i oprawach wlasnych. 
sprawozdania związków zawodowych drukarzy, w których stowarzyszali się m.in. robotnicy introligatorscy ${ }^{52}$ oraz sprawozdania i informatory szkolne, w których wspominano o zajęciach, a nawet pracowniach introligatorskich ${ }^{53}$. Wiele informacji, zwłaszcza o charakterze statystycznym, zawierają sprawozdania izb rzemieślniczych w różnych miastach ${ }^{54}$. Mniejszą wartość mają sprawozdania z działalności bibliotek i innych instytucji; mogą zawierać informacje finansowe, w tym kwoty wydatkowane na oprawy książek.

Śladem wydarzeń społeczno-politycznych są umowy zbiorowe oraz tabele płac, które powstawały najczęściej jako owoc działań strajkowych ${ }^{55}$. Polscy introligatorzy nie mieli zunifikowanego cennika za poszczególne roboty, po raz pierwszy opracowano go dopiero po II wojnie światowej ${ }^{56}$.

Druki ulotne wykorzystywane przez introligatorów istniały w wielu egzemplarzach, jednak ich funkcja zbliża je do dokumentów archiwalnych, częściej też bywają zachowywane w zbiorach archiwalnych niż bibliotecznych. W pierwszym rzędzie są to różnego rodzaju papiery firmowe $\mathrm{z}$ drukowanym nagłówkiem oraz blankiety rachunków, drugim rodzajem są ulotki lub foldery reklamowe. Obok nazwy firmy i jej adresu informowano w nich o ofercie oraz uzyskanych nagrodach. Wydawnictwa takie składały się na prezentację wizualną firmy, dlatego niektóre zakłady zamawiały dla siebie druki okazałe graficznie, czasem o modnym wzornictwie, drukowane typograficznie lub litograficznie, jedno- lub wielobarwnie. Niektóre firmy posiadały logo, które nawet mogło być zastrzeżone jako marka ochronna.

Wśród innych druków akcydensowych, mogących stanowić źródła do dziejów działalności poszczególnych introligatorów znajdują się wizytówki, a także ekslibrisy, gdyż w środowisku związanym zawodowo z książką było wielu bibliofilów. Specyficzny rodzaj akcydensów stanowią nalepki

52 Np. „Sprawozdanie Polskiego Związku Zawodowego Drukarzy, Odlewaczy Czcionek i Pokrewnych Zawodów za ... Rok” (za lata 1907, 1936-1938); „Sprawozdanie Związku Zawodowego Pracowników Przemysłu Poligraficznego w Polsce, Okręg Warszawa za Rok...” (19391945, 1947, 1948); „Sprawozdanie Związku Zawodowego Pracowników Przemysłu Poligraficznego w Polsce, Okręg Kraków za Rok 1946”; „Sprawozdanie Związku Zawodowego Pracowników Przemysłu Poligraficznego w Polsce, Okręg Łódź za... Rok istnienia” (1946-1947).

53 „Sprawozdanie z Działalności Miejskiego Muzeum Przemysłowego za Rok Szkolny... [1926-1927]" 1927.

54 „Sprawozdanie Izby Rzemieślniczej w Warszawie za ... Rok” (za lata 1933-1938); „Sprawozdanie Izby Rzemieślniczej w Krakowie za Rok” (za lata 1930-1938); „Sprawozdanie za Rok [1937. Izba Rzemieślnicza we Lwowie]" 1938.

55 Umowa zbiorowa $w$ przemyśle i rzemiośle introligatorskim $w$ Warszawie z 13 listopada 1935 roku, [Warszawa 1935]; Uktad zbiorowy pracy dla przemystu poligraficznego w Polsce, Warszawa 1947; Cennik i regulamin pracy introligatorów warszawskich. Projekt, Warszawa [ok. 1930]; Cennik minimalny introligatorów we Lwowie, [Lwów] 1914, toż 1921; Zryczaltowana tabela płac dla pracowników samodzielnych introligatorni rzemieślniczych, [b.m] 1948.

56 Cennik robót introligatorskich opracowany w dniach 27 i 28 IX 1947 r. na Ogólnopolskim Zjeździe Introligatorów w Lodzi, [b.m. b.r.]. 
introligatorskie, służące do oznakowywania (sygnowania) prac. Podobne etykiety stosowali fachowcy innych zawodów (aptekarze, kapelusznicy, księgarze) do ocechowania swych towarów. Nalepki introligatorskie najczęściej są wlepione w książki. Wykonywane były w różnych technikach drukarskich i graficznych (typografia, miedzioryt, litografia, wytłaczanie reliefowe), niektóre przez samych introligatorów. Nalepki, analogicznie jak ekslibrisy, stanowią obiekty kolekcjonerskie - jedna z kolekcji jest prezentowana w formie bazy internetowej. Opracowania tego zagadnienia, wydane w albumowej formie, mogą służyć za materiał porównawczy ${ }^{57}$.

\section{3. Źródła opisowe}

Wśród źródeł opisowych dla dziejów introligatorstwa XIX-XX w. w pierwszym rzędzie warto zwrócić uwagę na literaturę pamiętnikarską. Niestety, wzmianki dotyczące introligatorstwa i opraw są drobne i rozproszone, a brakuje jakiegokolwiek przewodnika ułatwiającego dotarcie do nich. Krystyna Bednarska-Ruszajowa w przeglądzie Biblioteki i książki w pamiętnikach polskich XVIII-XX wieku. Rekonesans źródlowy ${ }^{58}$ nie uwzględniła aspektu introligatorskiego. Wprawdzie w kilku pamiętnikach odnotowała obecność tematyki introligatorskiej, ale w wielu innych ją pominęła ${ }^{59}$. Wśród pamiętników i wspomnień należy rozróżnić dwa rodzaje: memuary pisane przez introligatorów i pamiętniki innych osób, wzmiankujących te tematy. Pomiędzy pierwszymi najcenniejsze są Wspomnienia starego introligatora, stanowiące fragment rękopiśmiennego pamiętnika poznaniaka Stanisława Haremzy; rękopis tych wspomnień jest przechowywany w trzech zbiorach bibliotecznych $^{60}$. Artykuł wspomnieniowy pióra lwowiaka Aleksandra Semkowicza

57 E. Pokorzyńska, Metody sygnowania opraw introligatorskich, „Spotkania z Zabytkami” 2013, nr 9-10, s. 55-58; Gallery of Book Trade Labels, Seven Roads, [online] http://sevenroads.org/ Bookish.html [dostęp 31.08.2018]; W. Spawn, T. Kinsella: Ticketed Bookbindings from nineteenth-century Britain, Pennsylvania, New Castle 1999; tychże, American signed bindings through 1876, New Castle, Pennsylvania 2007.

58 Kraków 2003.

59 Wymienia np. pamiętniki Teodora Kaczyńskiego Z żółtym kuferkiem (Warszawa 1987), wspominającego bibliotekarza i introligatora-amatora, Antoniego Kuźniarskiego z Latowicza oraz wspomnienia Mieczysława Opałka Ze wspomnień bibliofila (Wrocław 1960), który sam amatorsko oprawiał swoje książki. Natomiast relacjonując wspomnienia Jadwigi Waydel-Dmochowskiej Jeszcze o dawnej Warszawie (Warszawa 1960) K. Bednarska-Ruszajowa pomija tematykę introligatorską, chociaż autorka cały rozdział poświęciła introligatorniom.

60 Haremza S., Wspomnienia starego introligatora, [w:] Poznańskie wspominki: starzy poznaniacy opowiadaja, Poznań 1960, s. 126-146. Autor napisał dwa pamiętniki - pierwszy, obejmujący okres młodości znajduje się w BPTPN (Rkp. 830, Chwile młodych lat. Ludzie Poznania opowiadają, zebr. i opr. H. i K. Sosnowscy), drugi, z lat późniejszych, przechowywany jest w dwóch kopiach: w BKórn. (sygn. BK 13582) i Bibliotece KUL (sygn. Rkp. 525a). 
został ogłoszony w 1929 r. w „Polskiej Gazecie Introligatorskiej” ${ }^{1}$. Wspomnienia Kazimierza Hałacińskiego, który wprawdzie nie był zawodowym introligatorem, ale młode lata spędził w warsztacie ojca - Eustachego, krakowskiego introligatora, zostały wydane w postaci książki bibliofilskiej ${ }^{62}$. Bardzo skrótową autobiografię Jana Recmanika opublikowano w poświęconej mu monografii ${ }^{63}$. Swe wspomnienia wydał poznański introligator Stanisław Kwiatkowski ${ }^{64}$.

Nieco pamiętników pozostaje w rękopisach. Memuary A. Semkowicza zostały zebrane, zredagowane, przepisane i wzbogacone w objaśnienia przez syna mistrza - Władysława i są przechowywane w zbiorach rodzinnych ${ }^{65}$. Pamiętnik R. Jahody znajduje się w Archiwum Narodowym w Krakowie ${ }^{66}$. Nieznane pozostają losy pamiętnika Łukasza Kruczkowskiego, który był podstawą źródłową pracy magisterskiej, napisanej przez jego wnuczkę Bożenę, a później był widziany na rynku antykwarskim ${ }^{67}$.

Wśród pamiętników innych osób warto wyróżnić memuary postaci związanych z ruchem wydawniczym i księgarskim, w których znajduje się wiele materiału dotyczącego oprawiania wydawnictw ${ }^{68}$. Ciekawe wątki zawierają także wspomnienia osób z kręgu rodzinnego czy przyjacielskiego introligatorów, a także pamiętniki pisane przez bibliofilów oraz panie $\mathrm{z}$ warstwy inteligenckiej, które często obcowały z książkami i czasem szeroko opisywały sprawy związane z oprawą książek ${ }^{69}$.

Ważnym materiałem pośrednim w badaniach nad introligatorstwem są monografie poświęcone poszczególnym introligatorom i ich grupom. Są to opracowania, które można wielorako wykorzystywać źródłowo: poprzez zebraną faktografię, ikonografię, przypisy bibliograficzne - wiele z nich publikuje w całości lub cytatach materiały źródłowe ${ }^{70}$. Biogramy introligatorów

${ }^{61}$ A. Semkowicz, O tradycji zawodowej, „Polska Gazeta Introligatorska” 1929, nr 5, s. 53-56.

62 K. Hałaciński, O krakowskich introligatorach ubiegłego wieku, Kraków 1926.

63 J. Recmanik, Autobiografia, w: E. Pokorzyńska, Jan Recmanik1874-1949: artysta introligator, Bydgoszcz 2014, s. 71-77.

${ }_{64}$ S. Kwiatkowski, Moje pótwiecze przygody z introligatorstwem, [Poznań ok. 2001].

65 Autorka dysponuje kopią kserograficzną tego maszynopisu.

${ }_{66}$ ANK w Krakowie, sygn. 29/648/1 [rps], 29/648/44 [maszyn.], Pamiętnik Roberta Jahody.

67 B. Kruczkowska, Łukasz Kruczkowski jako introligator, działacz zawodowy i społeczny, praca mag., prom. J. Jarowiecki, Kraków, WSP 1980, (Archiwum Uniwersytetu Pedagogicznego w Krakowie, sygn. 87/80 Bibliot.). O obecności pamiętnika w antykwariacie krakowskim wspominał o. Anzelm Szteinke w trakcie rozmowy z autorką przeprowadzonej w 2009 r.

68 S. Dippel, O księgarzach, którzy przeminęli, Wrocław 1976; L. Fiszer, Wspomnienia starego księgarza, Warszawa 1959; H. Mortkowicz-Olczakowa, Pod znakiem kłoska, Warszawa 1962; W. Grzelak, Wśród autorów i książek, Warszawa 1975 i in.

69 I. Lorentowicz, Oczarowania, Warszawa 1975; Z. Rabska, Moje życie z ksiażka. Wspomnienia. T. 1, Wrocław 1959; J. Waydel-Dmochowska, dz. cyt. i in.

70 M. Kocójowa, Krakowski świat książki doby autonomii galicyjskiej (kształtowanie nowe- 
można znaleźć w słownikach biograficznych; ok. 70 życiorysów znajduje się w Stowniku pracowników książki polskiej ${ }^{71}$. Życiorysy najwybitniejszych mistrzów znajdują się w wielu innych wydawnictwach encyklopedycznych, niektóre mniej znane postacie odnotowano $\mathrm{w}$ informatorach regionalnych ${ }^{72}$. Biogramy kilku introligatorów znalazły się tomikach o charakterze publicystycznym oraz w przewodnikach po $\mathrm{cmentarzach}^{73}$.

Drukami, w których zamieszczano życiorysy są także wydawnictwa okazjonalne, jubileuszowe. Warto je polecić, zawierają bowiem także wykazy członków organizacji, wspomnienia, sprawozdania, rysy historyczne. Dla omawianego tematu istotne są księgi pamiątkowe cechów i związków zawodowych introligatorskich, organizacji drukarskich, zakładów poligraficznych oraz bibliotek ${ }^{74}$.

Źródła literackie sensu stricto nie są dla omawianego tematu obfite, a autorzy nie trudzili się w oddaniu zawodowych realiów życia introligatorów. W kilku utworach prozatorskich znajduje się krótki opis warsztatu będącego miejscem akcji, w innych bohater wykonuje jakiś produkt introligatorski. Także w znanych autorce utworach wierszowanych temat opraw książek lub pracy w zawodzie został potraktowany powierzchownie ${ }^{75}$.

go modelu w latach, 1867-1882), Kraków 1990; M. Myśliński, Introligatorzy krakowscy w wieku XIX w świetle dokumentów cechowych, „Kwartalnik Historii Kultury Materialnej” 2013, nr 4, s. 611-618.

${ }^{71}$ SPKP, pod red. I. Treichel, Warszawa 1972, Suplement, pod red. tejże, Warszawa 1986, Suplement 2, pod red. tejże, Warszawa 2000, Suplement 3, pod red. tejże, Warszawa 2010, Suplement 4, pod red. M. Rzadkowolskiej, Warszawa 2016.

72 Szereg biogramów introligatorów zamieszczono w Czy wiesz kto to jest? Stanisława Łozy (t. 1-2, Warszawa 1938-1939); biogramy Bonawentury Lenarta i Z. Zjawińskiego znajdują się w Stowniku artystów plastyków. Artyści plastycy Okręgu Warszawskiego ZPAP 1945-1970. Stownik biograficzny, Warszawa 1972, s. 309-310, 674-675; biogram Antoniego Oehla został opublikowany przez Helenę i Jana Mączników w Puławskim Stowniku Biograficznym. T. 2: L-P, Puławy 2000, s. 138, a Mariana Szulca w Toruńskim Stowniku Biograficznym. T. 7, pod red. K. Mikulskiego, Toruń 2014, s. 212-214.

73 O. Budrewicz, Baedeker warszawski. [T.] 2: Raczej o ludziach, Warszawa 1961; tegoż, Sagi warszawskie. Trzecia seria sensacyjnych i powszednich, romantycznych i prozaicznych dziejów rodzin warszawskich, Warszawa 1983; E. Szulc, Cmentarz ewangelicko-augsburski w Warszawie. Zmarli i ich rodziny, Warszawa 1989 i in.

74 J. Dobrzycki, Zarys dziejów introligatorstwa w Krakowie 1568-1968, Kraków 1968; M. Żynda, dz. cyt.; Informator 30 letniej działalności Sekcji Introligatorów w Bydgoszczy, [Bydgoszcz 1969]; Księga pamiątkowa Stowarzyszeń Drukarzy Krakowskich wydana w roku jubileuszowym 80-lecia Stowarzyszeń Drukarzy i Pokrewnych Zawodów oraz 60-lecia Stow. Emerytalnego «Siła», Kraków 1930; Ćwierćwiecze Sekcji Introligatorów Zwiazku Zaw. Pracowników Przemystu Poligraficznego w Polsce. Okręg-Poznań 1919-1944, [oprac. S. Haremza], Poznań 1946; 75 lat Okręgu Warszawskiego Związu Zawodowego Pracowników Poligrafii 1892-1967, [Warszawa 1968]; Dwadzieścia pięć lat Związu Zawodowego Pracowników Przemystu Poligraficznego w Polsce, Oddziału Toruńskiego 1920-1945, Toruń 1947; J. Bartnicki, 180 lat Zakładów Graficznych w Bydgoszczy na tle dziejów miasta Bydgoszczy 1806-1986, Warszawa 1986 i in.

75 M. Konopnicka, Mendel Gdański, „Przegląd Literacki”, dodatek do „Kraju” 1890, nr 16- 
Bogatym źródłem dla badań historycznych jest prasa. Większe artykuły można odnaleźć przy pomocy bibliografii specjalnych ${ }^{76}$ lub przeszukując przypisy i bibliografie załącznikowe. Systematyczne analizowanie całego ciągu numerów jest zasadne w przypadku tytułów, w których wielokrotnie występują artykuły związane z introligatorstwem, a są takimi „Polska Gazeta Introligatorska” (1928-1934), „Gazeta Przemysłowo-Rzemieślnicza” (1874-1939), „Grafika” (trzy periodyki noszące ten sam tytuł wychodzące w latach 1906, 1912, 1930-1939), „Przegląd Graficzny, Wydawniczy i Papierniczy” (1923-1939), „Wiadomości Graficzne” (1908-1939 i później), „Ognisko” (1895-1939), „Poligrafika” (1947- ).

Liczba tytułów prasowych i objętość numerów tak bardzo wzrosła w XIX i XX w., że tradycyjne wyszukiwanie w nich materiałów na określony temat staje się czasochłonne, a wręcz niewykonalne. Także bibliografowie nie podołali zadaniu zarejestrowania wszystkiego, na przykład siódmy tom Bibliografii Warszawy, obejmujący wydawnictwa ciągłe z lat 1795-1863 zawiera 24 opisy notek prasowych dotyczących introligatorstwa (reklamy, zmiany adresu, przyjazdy i wyjazdy z miasta, nekrologi, zawiadomienia o zebraniach cechu) ${ }^{77}$. W tomach obejmujących późniejsze okresy, w związku z lawinowym przyrostem drobnych notek w prasie, autorzy bibliografii zaniechali ich rejestrowania.

W ostatnich latach pojawiło się narzędzie służące do przeszukiwania zawartości dawnych publikacji, w tym wydawnictw prasowych: biblioteki cyfrowe. Zdigitalizowały one i wciąż digitalizują dawne czasopisma. Proces ten postępuje w odpowiedzi na palące problemy konserwacji zbiorów bibliotecznych - destrukcję publikacji drukowanych na papierze niskiej jakości, kwaśnym. Biblioteki cyfrowe za jedno z pryncypialnych zadań uznały digitalizację lokalnej, regionalnej prasy, która w najwyższym stopniu jest zagrożona rozpadem fizycznym. Technologia cyfryzacji zbiorów, obejmująca nie tylko skanowanie, czyli odwzorowanie wyglądu dokumentów, lecz także stworzenie rozpoznawalnej przez komputery warstwy tekstowej dzięki procesowi OCR (Optical Character Recognition), umożliwia masowe przeszukiwanie zbiorów dokumentów cyfrowych. System bibliotek cyfrowych wzbogacono o multiwyszukiwarki (np. Federacja Bibliotek Cyfrowych, Europeana), ale że przeszukują one jedynie metadane, to uzyskiwane wyniki są zawężone do

19 i liczne inne wydania samoistne; W. Zagórski (Chochlik), O własnych skrzydtach. Powieść, Warszawa 1891; E. Orzeszkowa, Pamiętnik Wacławy. Ze wspomnień młodej panny. T. 2, Warszawa 1959; K. Beylin, Jeden rok Warszawy 1875, Warszawa 1959; C. Kowalewicz, Pomoc introligatorska, „Wiadomości Graficzne” 1966, nr 3, s. 13.

76 Polska Bibliografia Bibliologiczna, Warszawa 1968-.

77 Bibliografia Warszawy, [T. 7]: Wydawnictwa ciagte 1795-1863, [red. nauk. J. Durko], Wrocław 1992, s. 78-79. 
obiektów, w których tytule lub hasłach rzeczowych występuje termin ,introligatorstwo". Tymczasem polskie biblioteki cyfrowe działające na oprogramowaniu dLibra umożliwiają wyszukiwanie pełnotekstowe prowadzone na poziomie konkretnej biblioteki cyfrowej (niestety w mechanizm ten nie zaopatrzono Cyfrowej Biblioteki Narodowej Polona). Na liście wynikowej pojawiają się dokumenty, które $\mathrm{w}$ treści zawierają poszukiwany termin. Po otwarciu konkretnego dokumentu, mechaniczne przeszukiwanie pełnotekstowe prowadzone jest w jego tekście i ukazuje się podświetlone poszukiwane słowo. Polskie biblioteki cyfrowe przez wiele lat korzystały z formatu prezencyjnego $\mathrm{Dj} \mathrm{Vu}$, który posiada doskonale opracowane funkcje przeszukiwania, a także kopiowania i eksportowania. Niestety, problemy z otwieraniem plików w tym formacie i udostępnienie wtyczki DjVu HTML5 pozbawiło użytkowników tych funkcji. Jednak jeśli dokument posiada warstwę tekstową (OCR) możliwe jest jej przeszukiwanie za pomocą skrótu klawiaturowego $\mathrm{Ctrl}+\mathrm{F}$, ale tylko na przeglądanej stronie.

Inną biblioteką cyfrową, oferującą dostęp do zawartości tekstowej zeskanowanych dzieł, jest filtr „Google Książki”78. Firma Google odwzorowała cyfrowo olbrzymią liczbę tytułów w różnych językach, w tym polskim. Dostępna jest funkcja przeszukiwania ich zawartości, w wyniku którego ukazują się otwarte strony z podświetlonymi poszukiwanymi słowami. Część książek obwarowana prawem autorskim nie jest udostępniana, ale i one są poddane przeszukiwaniu pełnotekstowemu, a w odpowiedzi udostępniane są co najwyżej trzy fragmenty stron wraz ze wskazówką, ile razy interesujące słowo występuje w całym tekście.

Źródłem do poznania techniki introligatorskiej są podręczniki zawodowe oraz fachowe artykuły. W XIX i na początku XX w. ukazywały się w języku polskim jedynie uproszczone podręczniki przeznaczone dla amatorów ${ }^{79}$; podręczniki kierowane do profesjonalnych introligatorów - Introligatorstwo A. Semkowicza oraz książkę o tym samym tytule autorstwa Zygmunta Zjawińskiego - wydano dopiero po wojnie ${ }^{80}$. Ponadto w okresie powojennym

78 Google Książki, [online] https://books.google.pl/ [dostęp 31.08.2018].

79 M. Radomczyk (Mosiołek), Domowa nauka oprawiania ksiązek. Z rysunkami, Warszawa 1899, toż 1908 i 1922; F. Dubrawski, Introligatorstwo w szkole. Podręcznik metodyczno-praktyczny dla nauczycieli robót ręcznych z 50 rycinami, Lwów-Warszawa 1925; W. Rajewska, Introligatorstwo w domu i w szkole z 24 rysunkami w tekście, Cieszyn 1924; M. Sowiński, Nauczanie robót ręcznych. Cz. 1: Oprawy brulionu, notesu, bloku, szkicownika, pamiętnika, książki w skórę, attas, szare płótno i tak dalej, złocenie, barwienie papierów i wiele innych. Cz. 2: Roboty z papieru, kartonu, tektury i pomoce naukowe, Kraków 1930-1925; W. Czyżycki, Zajęcia rękodzielnicze z papieru, kartonu, tektury. Wskazówki techniczne z licznemi rysunkami w tekście i tablicami, Poznań 1934.

80 A. Semkowicz, Introligatorstwo z krótkim zarysem historii zdobnictwa opraw $i$ 89 rycinami w tekście, Kraków 1948; Z. Zjawiński, Introligatorstwo, Warszawa 1966. 
pojawiło się kilka podręczników do introligatorstwa przemysłowego ${ }^{81}$. Nieco fachowych artykułów ukazało się na łamach różnych czasopism („Piast”, „Gazeta Przemysłowo-Rzemieślnicza”). Bogatym źródłem wiedzy fachowej są artykuły zamieszczane w wychodzącej w latach 1928-1934 „Polskiej Gazecie Introligatorskiej”. Redakcja próbowała w ten sposób wypełnić lukę w literaturze fachowej. Do „Gazety” dołączano także wydawany arkuszami podręcznik introligatorski, lecz zaprzestano jego publikacji po kilku pierwszych częściach.

Fakt, że aż do 1948 r. nie było polskiego podręcznika fachowego dla zawodu introligatorskiego nie oznacza braku potrzeby, zainteresowania ani prób jego stworzenia. W działalności wielu introligatorów pojawia się wątek tworzenia takiego dzieła (B. Lenart, Zdzisław Szafranek, J. Recmanik, Stefan Szczerbiński), lecz ich prace nie zostały dokończone ani wydane, niektóre uległy zniszczeniu podczas działań wojennych. Zachował się rękopis podręcznika S. Szczerbińskiego ${ }^{82}$, a niewykluczone że gdzieś istnieją inne tego rodzaju nieznane manuskrypty.

Brak polskich podręczników zawodowych badacz może wypełnić publikacjami obcojęzycznymi (francuskimi, niemieckimi, angielskimi), jakich sporo ukazywało się w XVIII-XX w. Trudno stwierdzić, czy polscy introligatorzy korzystali z tych podręczników, ale wiadomo, że wielu z nich z racji pochodzenia doskonale znało język niemiecki, a niektórzy odbywali zagraniczne wędrówki. Niezależnie od tego, czy były znane w środowisku polskich introligatorów, czy nie, obce publikacje są źródłem informacyjnym w zakresie technologii stosowanych w tamtych epokach.

We wszystkich typach źródeł pisanych występują materiały statystyczne. Mają formę wykazów lub ustrukturalizowanych tabel, a występują w źródłach archiwalnych urzędowych, cechowych, w sprawozdaniach rękopiśmiennych i drukowanych. W artykułach prasowych pojawiają się informacje liczbowe wplecione w tekst. W materiałach statystycznych znajdują się dane dotyczące ilości zakładów i pracowników, dochodów branży, a w archiwaliach bibliotecznych liczby oprawianych tomów i ponoszonych wydatków na oprawę. Na problemy związane z korzystaniem ze źródeł statystycznych wskazywali już badacze, podkreślając sprzeczności między danymi pochodzącymi z różnych źródeł, niekompletność, niejednolitość jednostek i dowolność metod statystycznych ${ }^{83}$.

${ }_{81}$ M.W. Bałandin, Introligatorstwo przemysłowe, tłumaczył W. Tacikowski, Warszawa 1965; I. Pietruczuk, H. Godlewski, W. Jędrych, Technika i technologia introligatorstwa przemystowego, Warszawa 1985; S. Magdzik, Introligatorstwo przemystowe. Podręcznik dla technikum, Warszawa 1988.

82 Rękopis podręcznika S. Szczerbińskiego znajduje się w zbiorach Muzeum Papiernictwa w Dusznikach, sygn. MD 978 AH.

83 B. Bieńkowska, Wokót raportu o stratach bibliotek polskich w czasie II wojny światowej, 


\section{3. Źródła niepisane}

\subsection{Oprawy książek.}

Efekt pracy introligatorów w postaci oprawionych książek, przechowywanych na bibliotecznych półkach, to najliczniej zachowane źródła do dziejów introligatorstwa. Niosą one ze sobą wiele informacji co do periodyzacji, technologii, wpływów artystycznych, lecz odczytanie ich wszystkich nie jest łatwe, a co gorsza, rzadko przynosi odpowiedź na najważniejsze pytania badawcze: kto, kiedy, dla kogo i dlaczego właśnie w taki sposób oprawił daną książkę. Podstawowy problem tkwi w anonimowości opraw, bowiem niewielki ich procent ma introligatorską sygnaturę, pozwalającą z pewnością przypisać ją konkretnemu warsztatowi. Anonimowa pozostaje większość opraw luksusowych, o wysokich walorach estetycznych i artystycznych. Jednak nawet przeciętne oprawy w swej masie dają wyobrażenie o tendencjach technicznych, materiałowych i zdobniczych panujących w poszczególnych okresach historycznych.

Mimo zachowania tak wielkiej liczby dawnych książek, dostęp do nich jest utrudniony; najefektywniejsze są badania przeprowadzane w miejscu przechowywania zbiorów, w magazynie bibliotecznym, na co trudno uzyskać zezwolenie. Stąd dobrym źródłem poznawania opraw są obiekty antykwaryczne i prywatne zbiory bibliofilskie. W zakresie wystroju opraw (okładek), badania $\mathrm{z}$ autopsji można zastąpić analizą materiału ikonograficznego, który został omówiony w dalszej części artykułu.

\subsection{Warsztaty i ich wyposażenie}

Rzemiosło jest dziedziną, w której zmiany następują niezbyt szybko jeszcze w okresie powojennym rzemieślnicy introligatorzy uprawiali swój zawód technikami tradycyjnymi. W warsztatach zachowało się dużo starych urządzeń i narzędzi, które wciąż jeszcze są wykorzystywane w pracy. Przełom ustrojowy roku 1989 spowodował problemy ekonomiczne większości warsztatów. Wiele z nich upadło, po części wyprzedając a po części złomując niepotrzebne urządzenia, ale wciąż jeszcze istnieją zakłady introligatorskie, które są dobrym źródłem poznania $z$ autopsji dawnych maszyn i narzędzi. Wyposażenie warsztatów introligatorskich jest także gromadzone w kilku

[w:] Symposia bibliologica. Dokumentacja księgozbiorów historycznych - wspótpraca krajowa i międzynarodowa. Skutki II wojny światowej dla bibliotek polskich, pod red. A. Mężyńskiego, Warszawa 1995, s. 88-89; M. Mlekicka, Wykorzystanie źródet drukowanych z lat 1795-1918 do badań nad dziejami ksiązki polskiej. Zarys metodologiczny, „Z Badań nad Polskimi Księgozbiorami Historycznymi" 1977, nr 3, s. 46. 
placówkach muzealnych w Polsce, przede wszystkim w Dziale Drukarstwa i Introligatorstwa Muzeum Historycznego Miasta Krakowa, powstałym na bazie pracowni introligatorskiej R. Jahody. Urządzenia introligatorskie gromadzą również: Muzeum Drukarstwa Warszawskiego, Izba Drukarstwa w Lublinie, Muzeum Papiernictwa w Dusznikach Zdroju, Muzeum Sztuki Drukarskiej i Papiernictwa w Supraślu, Muzeum Inżynierii Miejskiej w Krakowie oraz placówki prywatne: Muzeum Drukarstwa w Cieszynie, Muzeum Papieru i Druku w Łodzi, Muzeum Piśmiennictwa i Drukarstwa w Grębocinie, zbiór Leonarda Rosadzińskiego w Poznaniu, Leszka Knyrka w Bydgosz$\mathrm{czy}^{84} \mathrm{i}$ wiele innych.

Warsztaty są ponadto miejscem, gdzie można uzyskać informacje od osób aktywnych zawodowo oraz nawiązać kontakty z introligatorami emerytowanymi (źródła osobowe, historia mówiona), i skorzystać z ich wiedzy, doświadczenia oraz wspomnień.

\subsection{Ikonografia}

Najcenniejszym rodzajem ikonografii introligatorskiej są przedstawienia warsztatów z pracującymi w nich rzemieślnikami. We wcześniejszych stuleciach powstawały grafiki, przedstawiające pracownie introligatorskie, które bywają reprodukowane w wydawnictwach okazjonalnych i opracowaniach. Od końca wieku XIX posługiwano się techniką fotograficzną, wykonywano zdjęcia warsztatów i fabryk introligatorskich, chętnie robiono fotografie zbiorowe, szczególnie podczas zjazdów lub uroczystości. Zdjęcia introligatorów polskich, z przewagą krakowskich, zebrał Gustaw Schmager, sporządzony przez niego album zawierający fotografie zbiorowe oraz portretowe znajduje się w zbiorach Biblioteki Jagiellońskiej ${ }^{85}$. Wiele zdjęć, tableau i albumów znajduje się w Dziale Drukarstwa i Introligatorstwa Muzeum Historycznego Miasta Krakowa. Pojedyncze fotografie i całe albumy pozostają w rękach rodzin wielu introligatorów i pojawiają się na rynku antykwarskim.

Introligatorzy niekiedy wykonywali zdjęcia swych opraw, zazwyczaj prac artystycznych; bywają one przechowywane w archiwach firmowych lub rodzinnych.

Analiza reprodukcji opraw może zastąpić bezpośredni kontakt z książkami, jednak polskie publikacje nie dorównują zagranicznym albumom pod względem jakości ilustracji. Reprodukcje najczęściej publikowano w katalogach wystaw i zbiorów, a czasem jako ilustrację prasowego artykułu. Zwykle

${ }^{84}$ L. Knyrek swe zbiory prezentuje na stronie internetowej: wirtualne muzeum introligatorstwa, [online] http://muzeumintroligatorstwa.pl/ [dostęp 01.09.2018].

85 BJ, sygn. J.F.5337-5394, Album introligatorów polskich. Zebrał G. Schmager, Kraków 1967. 
były to zdjęcia czarno-białe, słabo oddające walory artystyczne opraw. Dopiero w ostatnich latach pojawiły się publikacje z dużymi ilustracjami dobrej jakości, umożliwiającymi lepsze zapoznanie się z obiektami ${ }^{86}$. Także w katalogach aukcji antykwarycznych przygotowywanych w ostatnich latach licznie występują fotografie opraw.

W obecnej dobie miejsce albumów z reprodukcjami zajmują internetowe bazy opraw. W Polsce utworzono dotychczas tylko bazę opraw BPTPN. Niestety, zawiera ona jedynie oprawy z dawnych wieków, a do tego nie jest od wielu lat rozwijana ${ }^{87}$. Tymczasem wiele bibliotek na całym świecie prowadzi bazy, w których udostępnia fotografie opraw, czasem także z różnymi detalami, oraz z opracowaniem. W latach 2010-2015 Konsorcjum Europejskich Bibliotek Naukowych (CERL) uznało udostępnianie zbiorów poprzez bazy opraw za zadanie pierwszorzędne w obszarze oprawoznawstwa ${ }^{88}$.

\section{Podsumowanie}

Prowadząc badania nad introligatorstwem XIX-XX w. można stawiać różne pytania badawcze, ale każde $\mathrm{z}$ nich wymaga doboru odpowiedniej bazy źródłowej. Źródła do badań nad introligatorstwem są bardzo różnorodne, W większości dość trudno dostępne, a brak odpowiedniego informatorium wymaga od badacza samodzielnego zbudowania warsztatu naukowego. Wielką nadzieją dla tej subdyscypliny bibliologii są różnego rodzaju platformy internetowe (katalogi biblioteczne, archiwa i biblioteki cyfrowe, bazy opraw, wystawy cyfrowe), które poszerzają bazę źródłową, ułatwiają dostęp do źródeł, przyspieszają i wspomagają prowadzenie prac badawczych.

\section{Bibliografia}

Źródła archiwalne:

Archiwum Biblioteki Narodowej, sygn. 1.552, 2.107, Akta introligatorni i pracowni konserwacji.

Archiwum Biblioteki Publicznej m. st. Warszawy:

sygn. A341/3, Akta Biblioteki Publicznej m. st. Warszawy,

86 J. Tomaszewski, Oprawy haftowane i tekstylne z XVI-XIX wieku w zbiorach polskich. T. 1-2, Warszawa 2013; L. Rosadziński, Ginace rzemiosło...; Kurtiak i Ley - edycje bibliofilskie 1989-2012. [Katalog], Koszalin 2012.

87 Baza opraw zabytkowych XV-XVIII w., Biblioteka Poznańskiego Towarzystwa Przyjació1 Nauk. [online] http://www.ptpn.poznan.pl/oprawy/ [dostęp 01.09.2018].

88 CERL, Strategic Plan, 2010-2015, Consortium of European Research Libraries, [online] http://www.cerl.org/about/development [dostęp 01.09.2018]. Zob też. E. Pokorzyńska, Kolekcje cyfrowe opraw zabytkowych, [w:] Oblicza przestrzeni informacyjnej $w$ dobie Web 2.0, pod red. K. Domańskiej, E. Głowackiej, P. Marca, Bydgoszcz 2016, s. 220-231. 
sygn. A1, A8-11, A74-79, A91, Akta Wydziału Czytelń Bezpłatnych Warszawskiego Towarzystwa Dobroczynności.

Archiwum Główne Akt Dawnych:

sygn. 1/191/7827, 7833, 7839, 7841, Akta tyczące się imigracji,

sygn. 1/99, Protokół rewizyi miasta wolnego Warszawy 1792,

sygn. 1/245/55, Przedstawienie sprawy [...] introligatora Aleksandra Millera, czeladnika

introligatorni Ignacego Leżyńskiego,

sygn. 1/194/1420-1422, Roboty introligatorskie.

Archiwum Narodowe w Krakowie:

sygn. 29/141, Cech introligatorów i puzderników w Krakowie,

Archiwum Państwowe w Bydgoszczy, sygn. 6/651 nr 9, 40, 41, Izba Rzemieślnicza w Bydgoszczy.

Archiwum Państwowe w Gdańsku, sygn. 10/300C, Cechy gdańskie.

Archiwum Państwowe w Opolu, sygn. 45/121, Cech introligatorów w Nysie.

Archiwum Państwowe w Poznaniu, sygn. 53/636/14, Cech introligatorów i konwisarzy w Poznaniu.

Archiwum Państwowe w Radomiu, sygn. 50/1335/17, Książka profesji introligatorskiej w Radomiu.

Archiwum Państwowe w Toruniu, sygn. 69/IV/V/1, Cech introligatorów.

Archiwum Państwowe w Toruniu, Akta miasta Torunia:

sygn. 69/1c, sekcja 6, Rzemiosło, handel, przemysł,

sygn. 69/1c/18420, Wykaz przybyłych czeladników rzemieślniczych,

sygn. 69/XVI/122, Rechnungen von der Raths-Buchdruckerei aus der Jahren 1782-1792.

Archiwum Państwowe w Szczecinie, sygn. 65/277, Cech introligatorów w Szczecinie.

Archiwum Państwowe w Warszawie:

sygn.72/1155/549, Akta dotyczące Towarzystwa Przemysłu Graficznego w Królestwie

Polskim,

sygn. 72/1151/977, Akta kontroli fabryki Leśniewskiego sygn. 72/1151/929, fabryki bra-

ci Charin,

sygn. 72/1155/454, Profesional'noje obščestwo tipografščikov', litografov', perepletči-

kov, i srodstviennych' im' professij Carstva Pol'skavo,

sygn. 72/1049/13, Księga rachunkowa cechu introligatorskiego z lat 1811-1830,

sygn. 72/714, vol. 15, nr aktu 1469, Spis inwentarza pozostałego po Józefie Pukszcie.

Archiwum Państwowe w Zielonej Górze, sygn. 89/946, Akta cechu introligatorów i kuśnierzy w Zielonej Górze.

Biblioteka Jagiellońska, sygn. J.F.5337-5394, Album introligatorów polskich.

Biblioteka Kórnicka, Dział Rękopisów, sygn. AB215-AB219, Rachunki introligatorskie.

Biblioteka Uniwersytetu Warszawskiego, Dział Rękopisów, sygn. 114-117/I, 167/IV, 309/IV, 15-16/V, Książki zleceń introligatorskich. 
Litewskie Państwowe Archiwum Historyczne, F 975, Wileński cech introligatorów.

Lwowska Narodowa Naukowa Biblioteka Ukrainy im. W. Stefanyka Oddział Rękopisów, Archiwum Zakładu Narodowego im. Ossolińskich, Fond 54, opis IV sygn. 338, opis V sygn. 37, 56, Akta introligatorni Ossolineum.

Muzeum Papiernictwa w Dusznikach, sygn. MD 978 AH, rkp. 1922, Stefan Szczerbiński, Podręcznik do introligatorstwa.

Muzeum Śląskie w Katowicach, sygn. T/46, Cech introligatorów lwowskich.

Zbiory Leonarda Rosadzińskiego, Poznańska książka wpisów wędrujących czeladników introligatorskich.

Źródła drukowane:

Przepisy prawne:

Die allgemeine Gewerbe-Ordnung, „Allgemeine Gesetzsammlung” 1845, t. 5, nr 2541.

Allgemeine Gewerbe-Ordnung für die Preußischen Staaten, nebst dem dazu gehörigen Entschädigungs-Gesetz: erlassen zu Berlin am 17. Januar 1845, Aachen 1845.

Gewerbeordnung für das Deutsche Reich, „Deutsches Reichsgesetzblatt” 1883, nr 15, s. $177-240$.

Gewerbeordnung für den Norddeutschen Bund, „Bundesgesetzblatt des Norddeutschen Bundes" 1869, nr 26, s. 245-282.

Handwerks-Ordnung für West-Preußen = Ordynacya Rzemieślnicza lub Utożenie porządkow rzemieślniczych dla Pruss Zachodnich. De Dato Berlin den 24. Januar 1774, Marienwerder 1774.

Kaiserliches Patent vom 20. December 1859, womit eine Gewerbe-Ordnung für den ganzen Umfang des Reiches, mit Ausnahme des venetianischen Verwaltungsgebietes und der Militärgränze, erlassen, und vom 1. Mai 1860 angefangen in Wirksamkeit gesetzt wird, „Reichs Gesetz-Blatt für das Kaisertum Oesterreich” 1859, nr 227, s. 619-644.

Postanowienie Xięcia Namiestnika Królewskiego de dato 31. Grudnia 1816 Roku względem urządzenia zgromadzeń rzemieślniczych, [b.m.] 1816; „Dziennik Praw” 1818, t. 4, s. 111-151; Zbiór przepisów administracyjnych Królestwa Polskiego, Warszawa 1866, t. 1, cz. 2, tytuł 2, s. 3-11; „Gazeta Warszawska” 1817, nr 3, dod. s. 51-52, nr 4, s. 67-76, nr 5, s. 91-93; „Gazeta Przemysłowo-Rzemieślnicza” 1905, nr 9-16.

Powszechny regulamin procederowy z dnia 17 Stycznia 1845. Ustawa tyczaca sie zaprowadzenia rad procederowych i różnych odmian powszechnego regulaminu procederowego, tudzież zaprowadzenia sądów procederowych z dnia 9. lutego 1849. Instrukcya dla ustanowionych podtug $\$ \S 37$. 38. urzadzenia z dnia 9. Lutego 1849, examinacyjnych komisyjów, Brodnica 1853.

Prawo o urządzeniu kunsztów, rzemiost i professyi. Ustawa z 30 grudnia 1820, „Dziennik Rozporządzeń Rządowych Wolnego, Niepodległego i Ściśle Neutralnego Miasta Krakowa i jego Okręgu" 1821, nr 78.

Prawo urządzenia cechu żydowskiego z 16 września 1833, „Dziennik Praw Wolnego Miasta Krakowa” 1833, nr 6341. 
Rozporzadzenie Prezydenta Rzeczypospolitej z dnia 7 czerwca 1927 r. o prawie przemystowym, „Dziennik Ustaw” 1927, nr 53, s. 697-720.

Seltsam F., Posselt E., Die österreichische Gewerbe-Ordnung, ed. 2, Wien 1885.

Urzadzenia cechowe. Rozporzadzenie Senatu Rzadzacego z 26 maja 1843, „Dziennik Praw Wolnego Miasta Krakowa” 1843, nr 2650.

Wydania źródeł:

Najstarszy dokument introligatorczyków poznańskich, „Polska Gazeta Introligatorska” 1928, nr 6, s. 86-88.

Oprawko H., Szczepaniec J., Materiały do działalności wydawniczej naczelnych władz powstańczych 1794 roku w Warszawie, „Ze Skarbca Kultury” 1964, t. 12, z. 16, s. 214-295.

Prawa, przywileje i statuta miasta Krakowa (1507-1795). T. 2: (1587-1696), z. 3, zebrał i wyd. F. Piekosiński, Kraków 1909, s. 1298-1324, 1331-1332.

Przepisy $w$ przedmiocie zadawania sztuk czeladniczych $i$ mistrzowskich wydane $w$ Warszawie dnia 21 kwietnia 1819 r. przez Radce Stanu Prezydenta Municypalności i Policyi Miasta Stołecznego Warszawy, [w:] Z dziejów rzemiosła warszawskiego, pod red. B. Grochulskiej, W. Prussa, Warszawa 1983, s. 316-318.

Statut cechu introligatorów poznańskich z roku 1574, „Polska Gazeta Introligatorska” 1929, nr 1, s. 2-3.

Statuty toruńskiego rzemiosła artystycznego i budowlanego z XVI-XVIII w., wyd. B. Dybaś, J. Tandecki przy współpr. M. Farbiszewskiego, Warszawa-Toruń 1990, s. 63-74.

Katalogi:

Katalog rękopisów Biblioteki Publicznej m. st. Warszawy. T. 1: Sygnatury 1-200, oprac.

J. Rudnicka, J. Górka, Warszawa 1974.

Katalog wystawy ksiażki lwowskiej od XVI do XIX wieku, Lwów 1928.

Katalog wystawy pięknej książki polskiej, Warszawa 1936.

Katalog Wystawy Introligatorskiej, Warszawa 1897.

Krause K., Gesammt-Catalog von Maschinen für die gesammte Papierindustrie, Leipzig 1899.

Kurtiak i Ley-edycje bibliofilskie 1989-2012, Koszalin 2012.

Mszały rzymskie w krajowych oprawach (wileńskich), Księgarnia Świętego Wojciecha, [Poznań 1934].

Mszały rzymskie w polskiej szacie i oprawach własnych, Księgarnia Świętego Wojciecha, [Poznań 1934].

Oprawy polskie, red. A. Żółtowski, Warszawa 1987.

Pamiatki starej Warszawy zebrane na wystawie urzadzonej staraniem T.O.N.Z.P. w maju i czerwcu 1911 roku, Warszawa 1911.

Pięć wieków drukarstwa warszawskiego, oprac. M. Rulikowski, Warszawa 1922.

Wystawa introligatorska w Miejskim Muzeum Przemysłowym w Krakowie, Kraków 1910. 
Wystawa oprawy książki urzadzona staraniem Towarzystwa Miłośników Książki w Krakowie w sali Racławickiej Muzeum Narodowego czerwiec-lipiec MCMXXV, [tekst M. Jarosławiecka, S.S. Komornicki], Kraków 1925.

Dokumenty życia społecznego i periodyki:

Cennik i regulamin pracy introligatorów warszawskich. Projekt, Warszawa [ok. 1930].

Cennik minimalny introligatorów we Lwowie, [Lwów] 1914, toż 1921.

Cennik robót introligatorskich opracowany w dniach 27 i 28 IX 1947 r. na Ogólnopolskim Zjeździe Introligatorów w Łodzi, [b.m. b.r.].

Ćwierćwiecze Sekcji Introligatorów Związu Zaw. Pracowników Przemysłu Poligraficznego w Polsce. Okręg-Poznań 1919-1944, [oprac. S. Haremza], Poznań 1946.

Dwadzieścia pięć lat Związku Zawodowego Pracowników Przemystu Poligraficznego w Polsce, Oddziału Toruńskiego 1920-1945, Toruń 1947.

„Księga Adresowa Przemysłu, Handlu i Finansów” 1922, 1926.

„Przemysł Fabryczny w Królestwie Polskiem” R. 4: 1908, R. 5: 1909, R. 6: 1910.

„Przemysł i Handel Królestwa Polskiego” R. 9: 1913.

„Sprawozdanie Izby Rzemieślniczej w Warszawie za ... Rok” (za lata 1933-1938).

„Sprawozdanie Izby Rzemieślniczej w Krakowie za Rok” (za lata 1930-1938).

„Sprawozdanie Polskiego Związku Zawodowego Drukarzy, Odlewaczy Czcionek i Pokrewnych Zawodów za ... Rok" (za lata 1907, 1936-1938).

„Sprawozdanie Związku Zawodowego Pracowników Przemysłu Poligraficznego w Polsce, Okręg Warszawa za Rok...” (za lata 1939-1945, 1947, 1948).

„Sprawozdanie Związku Zawodowego Pracowników Przemysłu Poligraficznego w Polsce, Okręg Kraków za Rok 1946”.

„Sprawozdanie Związku Zawodowego Pracowników Przemysłu Poligraficznego w Polsce, Okręg Łódź” (za lata 1946-1947).

„Sprawozdanie z Działalności Miejskiego Muzeum Przemysłowego za Rok Szkolny... [1926-1927]" 1927

„Sprawozdanie za Rok [1937. Izba Rzemieślnicza we Lwowie]” 1938.

Uktad zbiorowy pracy dla przemystu poligraficznego w Polsce, Warszawa 1947.

Umowa zbiorowa $w$ przemyśle i rzemiośle introligatorskim $w$ Warszawie z 13 listopada 1935 roku, [Warszawa 1935].

Zryczaltowana tabela płac dla pracowników samodzielnych introligatorni rzemieślniczych, [b.m] 1948.

Publikacje wspomnieniowe, literackie:

Beylin K., Jeden rok Warszawy 1875, Warszawa 1959.

Dippel S., O księgarzach, którzy przeminęli, Wrocław 1976.

Fiszer L., Wspomnienia starego ksieggarza, Warszawa 1959.

Grzelak W., Wśród autorów i książek, Warszawa 1975.

Hałaciński K., O krakowskich introligatorach ubiegłego wieku, Kraków 1926. 
Haremza S., Wspomnienia starego introligatora, [w:] Poznańskie wspominki: starzy poznaniacy opowiadaja, Poznań 1960, s. 126-146.

Informator 30 letniej działalności Sekcji Introligatorów w Bydgoszczy, [Bydgoszcz 1969]. Kaczyński T., Z żóttym kuferkiem, Warszawa 1987.

Konopnicka M., Mendel Gdański, „Przegląd Literacki”, dodatek do „Kraju” 1890, nr 16-19.

Kowalewicz C., Pomoc introligatorska, „Wiadomości Graficzne” 1966, nr 3, s. 13.

Księga pamiatkowa Stowarzyszeń Drukarzy Krakowskich wydana w roku jubileuszowym 80-lecia Stowarzyszeń Drukarzy i Pokrewnych Zawodów oraz 60-lecia Stow. Emerytalnego «Siła», Kraków 1930.

Kwiatkowski S., Moje pótwiecze przygody z introligatorstwem, [Poznań ok. 2001].

Lorentowicz I., Oczarowania, Warszawa 1975.

Mortkowicz-Olczakowa H., Pod znakiem kłoska, Warszawa 1962.

Opałek M, Ze wspomnień bibliofila, Wrocław 1960.

Orzeszkowa E., Pamiętnik Wacławy. Ze wspomnień młodej panny. T. 2, Warszawa 1959. Rabska Z., Moje życie z książka. Wspomnienia. T. 1, Wrocław 1959.

Semkowicz A., O tradycji zawodowej, „Polska Gazeta Introligatorska” 1929, nr 5, s. 53-56. 75 lat Okręgu Warszawskiego Zwiąku Zawodowego Pracowników Poligrafii 18921967, [Warszawa 1968].

Warchałowski J., Książka, Kraków 1909.

Waydel-Dmochowska J., Jeszcze o dawnej Warszawie, Warszawa 1960.

Zagórski W. (Chochlik), O własnych skrzydłach. Powieść, Warszawa 1891.

Podręczniki zawodowe:

Bałandin M.W., Introligatorstwo przemystowe, thumaczył W. Tacikowski, Warszawa 1965.

Czyżycki W., Zajęcia rękodzielnicze z papieru, kartonu, tektury. Wskazówki techniczne z licznemi rysunkami w tekście i tablicami, Poznań 1934.

Dubrawski F., Introligatorstwo w szkole. Podręcznik metodyczno-praktyczny dla nauczycieli robót ręcznych z 50 rycinami, Lwów-Warszawa 1925.

Magdzik S., Introligatorstwo przemysłowe, Warszawa 1988.

Pietruczuk I., Godlewski H., Jędrych W., Technika i technologia introligatorstwa przemystowego, Warszawa 1985.

Radomczyk M. (Mosiołek), Domowa nauka oprawiania książek. Z rysunkami, Warszawa 1899, 1908, 1922.

Rajewska W., Introligatorstwo w domu $i$ w szkole z 24 rysunkami w tekście, Cieszyn 1924.

Semkowicz A., Introligatorstwo z krótkim zarysem historii zdobnictwa opraw $i 89$ rycinami w tekście, Kraków 1948.

Sowiński M., Nauczanie robót ręcznych. Cz. 1: Oprawy brulionu, notesu, bloku, szkicownika, pamiętnika, ksiązki w skórę, atłas, szare płótno i tak dalej, złocenie, barwienie papierów $i$ wiele innych. Cz. 2: Roboty z papieru, kartonu, tektury i pomoce naukowe, Kraków 1930-1925.

Zjawiński Z., Introligatorstwo, Warszawa 1966. 
Opracowania:

Bartnicki J., 180 lat Zakładów Graficznych w Bydgoszczy na tle dziejów miasta Bydgoszczy 1806-1986, Warszawa 1986.

Bednarska-Ruszajowa K., Biblioteki i książki w pamiętnikach polskich XVIII-XX wieku. Rekonesans źródłowy, Kraków 2003.

Bibliografia Warszawy. [T. 7]: Wydawnictwa ciagte 1795-1863, [red. nauk. J. Durko], Wrocław 1992.

Bieńkowska B., Wokół raportu o stratach bibliotek polskich w czasie II wojny światowej, [w:] Symposia bibliologica. Dokumentacja księgozbiorów historycznych; wspótpraca krajowa i międzynarodowa. Skutki II wojny światowej dla bibliotek polskich, pod red. A. Mężyńskiego, Warszawa 1995, s. 85-92.

Budrewicz O., Baedeker warszawski. [T.] 2: Raczej o ludziach, Warszawa 1961.

Budrewicz O., Sagi warszawskie. Trzecia seria sensacyjnych i powszednich, romantycznych i prozaicznych dziejów rodzin warszawskich, Warszawa 1983.

Czy wiesz kto to jest? T. 1-2, pod red. S. Łozy, Warszawa 1938-1939.

Dobrzycki J., Zarys dziejów introligatorstwa w Krakowie 1568-1968, Kraków 1968.

Drexlerowa A.M., Wystawy wytwórczości Królestwa Polskiego, Warszawa 1999.

Drexlerowa A.M., Olszewski A.K., Polska i Polacy na powszechnych wystawach światowych 1851-2000, Warszawa 2005.

Garczewska-Semka K., Ozdobne montaże rysunków z kolekcji wilanowskiej: historia i materiały $w$ świetle źródel archiwalnych $i$ konserwacja rysunku Norblina «Zaprzysiężenie Konstytucji 3 Maja 1791», „Notes Konserwatorski” 2015, nr 17, s. 209-227.

Goumissi E., Ochrona książek i rękopisów w Zakładzie Narodowym im. Ossolińskich we Lwowie w latach 1900-1939, [w:] Ochrona zbiorów bibliotecznych. Praca zbiorowa, pod red. R. Nowickiego, J. Gomoliszek, K. Wodniak, Bydgoszcz 2016, s. 35-54.

Hohensee L., Sztuki egzaminacyjne naszych pradziadów, „Rzemiosło” 1948, nr 11, s. 15 18.

Iwańska-Cieślik B., Biblioteka kapituły katedralnej we Włocławku, Bydgoszcz 2013.

Iwańska-Cieślik B., Kapituła zleca oprawę ksiag - analiza rachunków i innych dokumentów kapituly katedralnej we Włocławku w poszukiwaniu opłat za usługi introligatorskie $w$ latach 1492-1863, [w:] Introligatorzy $i$ ich klienci $=$ Bookbinders and their customers, pod red. A. Wagnera, Torun 2017, s. 213-228.

Jabłońska E., Biblioteka Kórnicka skarbnica zbiorów Działyńskich i Zamoyskich, Toruń 2005.

Kocójowa M., Krakowski świat książki doby autonomii galicyjskiej (kształtowanie nowego modelu w latach 1867-1882), Kraków 1990.

Kruczkowska B., Łukasz Kruczkowski jako introligator, działacz zawodowy i społeczny, praca mag., prom. J. Jarowiecki, Kraków, WSP 1980, (Archiwum Uniwersytetu Pedagogicznego w Krakowie, sygn. 87/80 Bibliot.).

Lech M., Książka i czytelnictwo w Warszawie 1870 r. w świetle raportu inspektorów nadzoru w komitecie cenzury, „Rocznik Biblioteki Narodowej” 1971, t. 7, s. 395-421. 
Lech M., Materiały do dziejów książi i czytelnictwa $w$ okresie zaborów $w$ archiwach polskich, ,Rocznik Biblioteki Narodowej” 1969, t. 5, s. 23-57.

Lech M., Problematyka księgoznawcza $w$ zasobach archiwaliów dziewiętnastowiecznych, ,Studia o Książce” 1985, t. 15, s. 69-86.

Liefhebber P., Dokumenty przyjęć uczniów do cechu introligatorów i kuśnierzy w Zielonej Górze z początku XIX wieku, [w:] Kultura i społeczeństwo na Środkowym Nadodrzu w XIX i XX w. pod red. P. Bartkowiaka, D. Kotlarka, Zielona Góra 2008, s. 166-173.

Mańkowski A., Dzieje drukarstwa i piśmiennictwa polskiego w Prusiech Zachodnich wraz ze szczegółowa bibliografią druków polskich zachodniopruskich, „Roczniki Towarzystwa Naukowego w Toruniu” 1906, R. 13, s. 260-299.

Mącznik H., Mącznik J., Puławski Słownik Biograficzny. T. 2: L-P, Puławy 2000.

Mlekicka M., Wykorzystanie źródet drukowanych z lat 1795-1918 do badań nad dziejami książki polskiej. Zarys metodologiczny, „Z Badań nad Polskimi Księgozbiorami Historycznymi” 1977, nr 3, s. 23-56.

Mlekicka M., Rogala J., Księgarnia wydawnicza Józefa Pukszty w Warszawie (18151834), ,Roczniki Biblioteczne” 1966, t. 10, z. 1-2, s. 91-140.

Myśliński M., Introligatorzy krakowscy w wieku XIX w świetle dokumentów cechowych, „Kwartalnik Historii Kultury Materialnej” 2013, nr 4, s. 611-618.

Nowakowski A., Rosadziński L., «Witajcie koledzy» - poznańska «Książka wpisów wędrujacych czeladników introligatorskich», „Biblioteka” 2010, nr 14, s. 21-31.

Pokorzyńska E., Introligatorstwo w Bydgoszczy w świetle dokumentacji egzaminów zawodowych z lat 1901-1933, „Kronika Bydgoska” 2011, nr 33, s. 83-102.

Pokorzyńska E., Introligatorzy toruńscy w XIX i pierwszej połowie XX wieku, [w:] Dawnych ksiag niesyty. Tom studiów dedykowanych profesorowi Januszowi Tondelowi na siedemdziesięciolecie urodzin, pod red. I. Imańskiej, A. Wagnera, Torun 2016, s. 317-339.

Pokorzyńska E., Introligatorzy warszawscy w świetle akt Komisji Rządowej Przychodów i Skarbu z lat 1822-1869, „Rocznik Warszawski” 2007, nr 35, s. 285-309.

Pokorzyńska E., Jan Recmanik 1874-1949: artysta introligator, Bydgoszcz 2014.

Pokorzyńska E., Kolekcje cyfrowe opraw zabytkowych, [w:] Oblicza przestrzeni informacyjnej $w$ dobie Web 2.0, pod red. K. Domańskiej, E. Głowackiej, P. Marca, Bydgoszcz 2016, s. 220-231.

Pokorzyńska E., Metody sygnowania opraw introligatorskich, „Spotkania z Zabytkami” 2013, nr 9-10, s. 55-58.

Pokorzyńska E., Z dziejów introligatorni Wojewódzkiej i Miejskiej Biblioteki Publicznej im. dr. Witolda Betzy w Bydgoszczy, Bydgoszcz 2013.

Polska Bibliografia Bibliologiczna, Warszawa 1968-.

Puchalski J., Źródła do historii bibliotek $w$ Polsce w latach 1918-1947. Studium bibliologiczne, Warszawa 2007.

Rodkiewiczówna J., Cech introligatorski w Wilnie. Zarys historyczny, Wilno 1929.

Rosadziński L., Ginace rzemiosło. Śladami poznańskich introligatorów, Poznań 2011. 
Rudnicka J., Biblioteka Wilanowska, Warszawa 1966.

Stownik artystów plastyków. Artyści plastycy Okręgu Warszawskiego ZPAP 1945-1970. Stownik biograficzny, Warszawa 1972.

Stownik pracowników książi polskiej, pod red. I. Treichel, Warszawa 1972, Suplement, pod red. tejże, Warszawa 1986, Suplement 2, pod red. tejże, Warszawa 2000, Suplement 3 , pod red. tejże, Warszawa 2010, Suplement 4, pod red. M. Rzadkowolskiej, Warszawa 2016.

Spawn W., Kinsella T., American signed bindings through 1876, New Castle, Pennsylvania 2007.

Spawn W., Kinsella T., Ticketed Bookbindings from nineteenth-century Britain, Pennsylvania, New Castle 1999.

Szulc E., Cmentarz ewangelicko-augsburski w Warszawie. Zmarli i ich rodziny, Warszawa 1989.

Szymańska K., Introligatorzy i księgarze w Lesznie w XVIII w., „Roczniki Biblioteczne” 1999, t. 43, s. 105-119.

Tomaszewski J., Oprawy haftowane i tekstylne z XVI-XIX wieku w zbiorach polskich. T. 1-2, Warszawa 2013.

Toruński Słownik Biograficzny. T. 7, pod red. K. Mikulskiego, Toruń 2014.

Tyszkowski W., Statut Konfraternii Kunsztu Introligatorskiego we Lwowie z 1740 r., „Ze Skarbca Kultury” 1978, t. 24, nr 30, s. 37-51.

Zamrzycka J., Introligatorzy toruńscy od XV do XVI/XVII wieku. Typologia cech warsztatowych, Toruń 2015.

Żynda M., Introligatorstwo poznańskie 1574-1975, Poznań 1975.

Strony internetowe:

Baza opraw zabytkowych XV-XVIII w., Biblioteka Poznańskiego Towarzystwa Przyjaciół Nauk, [online] http://www.ptpn.poznan.pl/oprawy/ [dostęp 01.09.2018].

CERL, Strategic Plan, 2010-2015, Consortium of European Research Libraries, [online] http://www.cerl.org/about/development [dostep 01.09.2018].

Drukarstwo i introligatorstwo, Muzeum Historyczne Miasta Krakowa, [online] http://www.mhk.pl/zbiory/drukarstwo-i-introligatorstwo [dostęp 08.08.2018].

geneteka.genealodzy.pl, [online] http://geneteka.genealodzy.pl/ [dostęp 28.08.2018].

Gallery of Book Trade Labels, Seven Roads, [online] http://sevenroads.org/Bookish. html [dostęp 31.08.2018].

Google Książki, [online] https://books.google.pl/ [dostęp 31.08.2018].

wirtualne muzeum introligatorstwa, [online] http://muzeumintroligatorstwa.pl/ [dostęp 01.09.2018].

szukajwarchiwach.pl., [online] https://szukajwarchiwach.pl/ [dostęp 28.08.2018].

Wyszukiwarka - Księgi rejestrowe RHA - Archiwum Państwowe w Warszawie, [online] https://www.warszawa.ap.gov.pl/wyszukiwarki/rha/index.html [dostęp 28.08.2018]. 